\title{
THE TYPOLOGY OF WH-MOVEMENT. WH-QUESTIONS IN MALAY
}

\author{
Peter Cole and Gabriella Hermon
}

\begin{abstract}
This article investigates the complex facts of Malay wh-questions, and suggests a theory of how Malay wh-questions fit into the typology of wh-questions permitted by a Minimalist conception of Universal Grammar. The paper examines the principles that account for overt $w h$-movement, $w h$-in-situ and partial $w h$-movement in Malay. We argue that the apparent optionality seen in Malay reduces to whether, in the lexicon, a question word consists of an operator and variable combined in a single word, or of a variable bound by a separate, phonologically null operator. We then apply the analysis based on Malay to other languages (primarily, to Chinese and English), and show that the principles employed for Malay are sufficient to explain the variation in $w h$-question formation among these languages.
\end{abstract}

\section{Introduction}

The purpose of this paper is to describe the complex facts of $w h$-movement in Malay, ${ }^{1}$ and to suggest a theory of how Malay wh-questions fit into the typology of wh-questions permitted by Universal Grammar. We shall argue that these facts can best be understood by examining them within the context of a deterministic approach to syntax like that of the Minimalist Program (Chomsky 1993 and 1995, inter alia). Our focus is on the principles that

* Earlier versions of this paper were presented at the linguistic colloquia of the Girona Summer School of Linguistics (Universitat de Girona), the National University of Singapore, Tel Aviv University, Universiti Sains Malaysia, and the University of Pennsylvania. We thank the audiences at those talks for their very helpful comments. Thanks are due in particular to Lubna Alsagoff, Lisa Cheng, Bob Franks, David Gil, Alex Grosu, Julia Horvath, James Huang, Mashudi Kader, Jaklin Kornfilt, K. P. Mohanan, Tara Mohanan, Tanya Reinhart, Luigi Rizzi, Rogayah Abd Razak, and Tali Siloni with whom we discussed the issues in this paper over recent years. Norhaida Aman assisted us with every aspect of this paper and deserves special thanks for all her help. This paper is the indirect outgrowth of our work on reflexives in Malay, which was supported by the National Science Foundation (grants SBR-9121167 and INT-9423291). We thank our native speaker consultants Lila, Noraza, Norhaida, and Suriani for their patient help and we would also like to acknowledge the assistance of the Dept. of English Language and Literature of the National University of Singapore, the Center for Languages and Translation of the Universiti Sains Malaysia, and the following units of the University of Delaware: the Dept. of Linguistics, the Dept. of Educational Studies, the College of Arts and Science, International Programs and Special Sessions, and the Center for Advanced Studies, all of which provided assistance or support for this research.

1 The variety of Malay on which this paper is based is the Malay spoken by educated speakers in Singapore. Some variety of Malay is spoken by about 200,000,000 inhabitants of Brunei, Indonesia, Malaysia, and Singapore. There is reason to believe that there is considerable variation in the syntax of the various social and geographical dialects, but this is a relatively unstudied topic, especially with respect to the syntax of the colloquial language. The reader should, therefore, bear in mind that the examples cited here are not intended to be exemplary of formal, prescriptively correct Malay or Indonesian, nor are the judgments claimed to hold for all colloquial dialects. 
account for overt wh-movement, covert movement, and unselective binding of a $w h$-variable in Malay. We then consider how well the analysis based on Malay elucidates our understanding of the properties of wh-questions across languages.

\subsection{Some theoretical assumptions}

The work that follows is based on certain theoretical assumptions that we take to be central to Minimalism as a research program:

A. All languages display the same underlying architecture. The only difference among languages is in the inventory of words/morphemes. Universal Grammar (UG) is not subject to parameterization.

B. There is no optionality in syntactic principles. Optionality in language is due to differences in lexical items/morphemes.

C. All the grammatical properties of UG itself are derived from the interface of syntax and extra grammatical systems such as logical interpretation and phonetic production. An important instantiation of the requirement that grammatical principles derive from properties of the interface is the principle of Full Interpretation (FI). FI requires that all elements necessary for semantic interpretation must be present at LF and that all elements present at LF must participate in assigning an interpretation.

FI has a specific corollary with regard to questions. Given the usual assumptions about the semantics of questions, FI requires that a wh-question must have an operator/variable structure along the following lines, where OP is a question operator binding a variable, $x$ :

$$
\mathrm{OP}_{\mathrm{x}}[\ldots x \ldots]
$$

We shall refer to this corollary of FI as the Variable Binding Condition. We take the Variable Binding Condition to be a bare output condition, and, therefore, sufficient to motivate movement. ${ }^{2}$

D. No movement rule applies unless its application is required by the needs/ properties of some lexical item. When the requirements of a lexical item can be satisfied without movement, no rule will apply. Functional heads that have uninterpretable features (such as a STRONG D feature on C) will force movement of a category with matching features to check their STRONG feature before spell-out. This is the only source of movement before spellout. Thus, constraints such as Rizzi's Wh-Criterion (Rizzi 1991), which requires $w h$-movement in the syntax, must be viewed as morphosyntactic

\footnotetext{
2 See the analysis of Partial Wh-Movement in Malay in section 5.5, in which the need to satisfy the Variable Binding Condition motivates LF wh-expletive replacement. An alternative explanation for LF $w h$-expletive replacement would be the need to eliminate expletives from the representation of the sentence prior to LF. Like the Variable Binding Condition, LF expletive replacement is an instance of movement that is motivated by the requirements of FI rather than the need to satisfy the morphosyntactic requirements of features.
} 
requirements, forcing movement prior to spell-out, due to the fact that the matrix $\mathrm{C}$ has a STRONG Q feature ( $w$ h-feature) that needs to be checked by a wh-feature that moves into the checking domain of $\mathrm{C}$.

To be more precise, movement for checking a strong feature is feature movement with pied-piping of the lexical material (pied-piping of the whword), since the movement necessarily occurs pre-spell-out. If there is any movement at LF, it is by definition only feature movement, since no piedpiping need take place.

E. Principles of economy of derivations as detailed in Chomsky (1995) also apply. In particular, movement is more costly than merger (base generation). Thus, when there is competition between two derivations based on the same numeration, one of which involves movement and the other does not, the derivation without movement will win out.

\section{Some Facts About Malay Wh-Questions}

In this section we review the options for wh-question formation in Malay. In sections 3-4, we show that $w h$-in-situ, fully moved wh and partially moved wh have different distributional properties. In section 5 , we will provide a deterministic analysis for these options and show how, in the theoretical context described in section 1 , different options fall out from the interaction of universal principles with different lexical items/morphemes in Malay. We explicitly reject an analysis in which the choice between the "move" and "don't move" options for wh-phrases in Malay is due to whether what is spelled out is the head or tail of a chain. We also provide arguments against an analysis in which the properties of in-situ $w h$ are due to clausal pied-piping at LF. Finally, in section 6, we apply the analysis developed for Malay to Chinese and to English (each taken as representative of the class of languages with similar properties), and show that it predicts correctly the properties of these languages as well. ${ }^{3}$

\subsection{Movement possibilities}

The possibilities for wh-questions in Malay are similar to those described by Saddy $(1991,1992)$ for Indonesian. ${ }^{4}$ There are three types of wh-questions

\footnotetext{
${ }^{3}$ We shall not discuss the restrictions on $w h$-in-situ in Iraqi Arabic as described by Ouhalla (1996). Ouhalla points out that the distributional restrictions on Iraqi Arabic do not appear to be governed by Subjacency but rather by Binding Theoretic considerations. Thus, Ouhalla proposes that the $w h$-in-situ in these languages is a pronominal anaphor rather than an operator or a variable. If Ouhalla is correct regarding Iraqi Arabic, it would mean that not only Subjacency but also the Binding Theory is relevant to the determination of $w h$-in-situ in certain languages.

${ }^{4}$ Our findings regarding $w h$-questions in Malay duplicate the general picture found previously by Saddy for Indonesian. There are, however, numerous differences as well. Where these differences are relevant to the issues under discussion, they are mentioned below. In addition, see Kader (1976) for a general study of questions in formal Malay. While this work is primarily on yes/no questions, it also provides insightful analyses of a number of aspects of $w h$-questions. See also Rogayah (1995).
} 
found in Malay, wh that is moved to its position of understood scope, $w h$-insitu and partially moved $w h$. We argue in section 5 that the various types of questions are derived very differently. Wh-in-situ, we claim, does not exhibit movement at any level and we argue that a principle of Unselective Binding (in the spirit of Heim 1982 and Reinhart 1993) is involved in the derivation of this construction. Full movement is shown to follow from the feature checking requirements of the matrix $\mathrm{Q}$, while Partial Movement is derived from overt movement followed by LF movement of the wh-Operator (OP henceforth).

The possibilities for $w h$-questions are illustrated in (1)-(3):

(1) Wh Moved to Its Scopal Position ${ }^{5}$

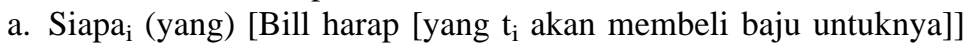
Who (that) Bill hope that will buy clothes for him

'Who does Bill hope will buy clothes for him?'

b. Kenapa $\mathrm{K}_{\mathrm{i}}$ [awak fikir [dia pergi $\mathrm{t}_{\mathrm{i}}$ ]]

why you think he leave

'Why do you think he left?'

(2) Wh-In Situ

a. Ali memberitahu kamu tadi [Fatimah baca apa]

Ali informed you just now Fatimah read what

'What did Ali tell you Fatimah was reading?'

b. Bill harap [guru itu akan mendenda siapa]

Bill hope teacher that will punish who

'Who does Bill hope that teacher will punish?'

5 Cheng (1991) and Martohardjono (1993) have each argued that similar structures in Indonesian do not involve $w h$-movement. Cheng presents an analysis of sentences like (1) in terms of a focus construction, with yang interpreted as a focus marker. Martohardjono also analyzes these as focus constructions, with the $w h$-word as the subject of a clause in which a headless relative clause is the nominal predicate. Unlike Cheng, who presumably would allow for focus movement in these sentences, Martohardjono argues that no movement whatsoever is involved in deriving such sentences. Her main argument against movement is based on her claim that in focus constructions in Indonesian (as in relative clauses generally), a subject-object asymmetry is observed: only subjects can be affected (i.e., only subjects can be relativized or focused). This constraint is taken to be applicable to base generated structures and not to be a constraint on movement.

The main argument against a no-movement approach for Malay is the fact that sentences like those in (1) obey constraints on movement, as is shown below. Martohardjono's no-movement account does not provide a satisfactory explanation for the sensitivity of examples like those of (1) to syntactic islands. See Cole \& Hermon (1997) for discussion.

In addition, at least in the Malay of our informants, there is no subject-object asymmetry in Malay for relativization. Moreover, for wh-questions, yang is optional in the colloquial speech of our informants. However, we claim that, in addition to the options with yang, (which we believe Cheng was correct in analyzing as a cleft-like construction, with covert movement of a focus operator), Malay also has wh-movement to Spec of CP. Note that Kader (1976) and Saddy (1991, 1992) also argue for a movement analysis for Indonesian for examples like (1). 
(3) Partially Moved $W h^{6}$

a. Ali memberitahu kamu tadi [CP apai (yang) [IP Fatimah baca $\mathrm{t}_{\mathrm{i}}$ ]] Ali told you just now what (that) Fatimah read

'Ali told you just now, what was Fatimah reading?'

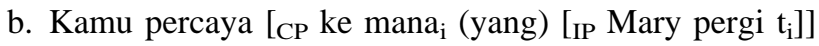
you believe to where (that) Mary go

'Where do you believe (that) Mary went?'

c. John fikir [kenapa ${ }_{i}\left(\right.$ yang) Mary rasa [Ali dipecat $t_{i}$ ]]

John think why (that) Mary feel Ali was fired

'Why does John think (that) Mary felt Ali was fired?'

In (1) the wh-words siapa 'who' and kenapa 'why' have moved from a position within the complement clause to the beginning of the matrix clause, a position which, as in English, we take to be the specifier of the matrix CP.

In contrast, in (2), as in Chinese and Japanese, the wh-words apa 'what' and siapa 'who' remain in-situ in the complement clause. As in similar examples in Chinese and Japanese, the $w h$-words are understood to have scope over the sentence as a whole, just as in (1). ${ }^{7}$ Finally, in (3), the whwords apa 'what', ke mana 'to where', and kenapa 'why' have moved to the beginning of the clause in which they originate or to the beginning of the intermediate clause, to the pre-complementizer position. We take this position to be the specifier of the subordinate $\mathrm{CP}{ }^{8}$

\subsection{Nominal versus adverbial wh-phrases}

While nominal wh-phrases like apa 'what', siapa 'who', perempuan mana 'which woman', and di mana 'where, in which (place)' can occur in any of the three positions just mentioned (scopal Spec, CP, in-situ, intermediate Spec, CP), adverbial $w h$-words (i.e., adverbial adjuncts) must undergo movement and cannot remain in-situ:

6 There are a number of arguments that these examples involve partial $w h$-movement rather than scrambling. Note that in (3c) kenapa 'why' has moved entirely out of its own clause to the beginning of the intermediate clause. This example is incompatible with a clause internal scrambling analysis of the data. For additional arguments that the movement in (3) is indeed to Spec CP, see Hermon \& Cole (in preparation).

7 In Saddy (1991) it is claimed for Indonesian that the wh-in-situ has a slightly different interpretation from the fully moved $w h$, akin to a quiz master question in English. Saddy's evidence comes (partially) from his claim that a list interpretation is impossible with in-situ questions. Our Malay informants, however, had no problems in giving a list answer to questions like:

(i) Siapa kamu fikir beli apa?

who you think buy what

'Who did you think bought what?'

${ }^{8}$ See section 5.5. 
(4) a. Kenapa Fatimah menangis?

why Fatimah cry

'Why did Fatimah cry?'

b. *Fatimah menangis kenapa?

Fatimah cry why

'Why did Fatimah cry?'

(5) a. Bagaimana Ali memandu kereta?

how Ali drive car

'How does Ali drive the car?'

b. *Ali memandu kereta bagaimana?

Ali drive car how

'How does Ali drive the car?'

These are to be contrasted with nominal adjuncts, which are well-formed insitu. ${ }^{9}$

a. Di mana Ali membeli pangsapuri?

at where Ali buy condominium

'Where did Ali buy a condominium?'

b. Ali membeli pangsapuri di mana?

Ali buy condominium at where

'Where did Ali buy the condominium?'

\section{Distributional Properties of Fully Moved and In-Situ Wh-Questions}

We shall now examine the distributional properties of fully moved and in-situ $w h$-questions. Our principal goal at this point in the paper is to determine whether the question type under consideration employs movement in its derivation. In order to do this, we examine two sets of properties that might reveal whether movement has occurred: 1) the sensitivity of the various question types to syntactic islands, and 2) the possible occurrence of the morpheme meng- in conjunction with these question types. As seen below, sensitivity to syntactic islands is indicative that movement is involved in the derivation of the question type under study. Similarly, the obligatory omission of meng- with verbs that normally take this prefix is indicative of movement. ${ }^{10}$

9 By "nominal adjunct" we mean an adjunct containing an NP rather than an adverb. In English for what reason is a nominal adjunct while why is an adverbial adjunct.

${ }^{10}$ One could raise the question of whether the existence of island effects is universally an indication of movement having taken place. As pointed out by an anonymous reviewer, there exist languages (such as Romanian and Bulgarian) in which an overtly moved $w h$ does not seem to obey Subjacency. We do not think this is a serious problem for our assumption that movement in general is island sensitive. Given the description in Rudin (1988), these languages have multiple Spec,CP positions and hence allow multiple overt $w h$-movement. As argued in Comorovski (1986) and Rudin (1988), this voids the wh-island (which is a Subjacency effect) but other islands (such as the CNPC) still limit movement. Thus, Subjacency holds for movement in general even in multiple-wh languages.

Another potential problem is languages that seem to obey islands and in which no overt movement has occurred. Georgopoulos (1985) argues that in Palauan wh-questions and focal 


\subsection{Syntactic islandhood}

In this section we compare the properties of overt $w h$-movement and $w h$-insitu with respect to islandhood. We show that overt movement not only obeys island restrictions (both strong and weak islands, in the sense of Cinque 1990) but it also has the effect of creating $w h$-islands with respect to the movement of other $w h$-phrases. In contrast, $w h$-in-situ neither obeys island restrictions nor does the presence of $w h$-in-situ create a $w h$-island. ${ }^{11}$ We now present the evidence that overt $w h$-movement in Malay obeys island constraints such as Subjacency: Overt $w h$-movement in Malay is not possible from either strong or weak islands.

(7) Ungrammatical Overt Movement from Relative Clauses (CNPC)

a. *Di mana ${ }_{i}\left[\mathrm{kamu}\right.$ fikir [Ali suka [perempuan yang tinggal $\left.\mathrm{t}_{\mathrm{i}}\right]$ ]]

At where you think Ali like woman who live

'You think Ali likes woman who lives where?'

b. *Dengan siapa $\mathrm{i}_{\mathrm{i}}\left[\mathrm{kamu}\right.$ sayang [perempuan [yang telah berjumpa $\mathrm{t}_{\mathrm{i}}$ ]]]

With who you love woman who already meet

'You love the woman who met who?'

(8) Ungrammatical Overt Movement from Sentential Subject

${ }^{*}\left[\mathrm{CP}\right.$ Siapa $_{\mathrm{i}}\left[\mathrm{t}_{\mathrm{i}}\right.$ yang [Ali mengahwini $\left.\mathrm{t}_{\mathrm{i}}\right]$ mengecewakan ibunya]

who that Ali married upset his mother

'Who did that Ali married upset his mother?'

(9) Ungrammatical Overt Movement from Adjunct Island

*Apa $a_{\mathrm{i}}$ (yang) Ali dipecat [ kerana dia beli $t_{\mathrm{i}}$ ] what (that) Ali was fired because he bought $t_{i}$

'Ali was fired because he bought what?'

(10) Ungrammatical Overt Movement from $W h$-Islands

a. ${ }^{*} \mathrm{Apa}_{\mathrm{i}}$ (yang) [awak agak [di mana $\mathrm{j}_{\mathrm{j}}$ [Mary beli $\left.\mathrm{t}_{\mathrm{i}} \mathrm{t}_{\mathrm{j}}\right]$ ]]

what that you wonder where Mary bought

'What do you wonder where Mary bought?'

b. ${ }^{*}{ }^{A p a} a_{i}$ (yang) awak agak [sama ada Ali ternampak $\mathrm{t}_{\mathrm{i}}$ ] what that you wonder whether Ali saw

'What did you wonder whether Ali saw?' (From Rogayah 1995)

elements are base generated in a pre-CP focus position and that a null resumptive pronoun (rather than a trace) shows up in the gap position. This chain is, however, subject to islands constraints and also triggers agreement on any intervening verbs (a phenomenon we take to be similar to the verbal prefix deletion in Malay). Thus, there may be languages in which a non-movement chain is island sensitive. As discussed below, it is not possible, however, to analyze wh-questions as chains involving a true resumptive pronoun in Malay.

11 Similar results were found independently by Saddy (1991) and Rogayah (1995). 
(11) Ungrammatical Overt Movement from Negative Island

a. Siapa $a_{i}$ (yang) Ali tidak fikir [Fatimah suka $\left.t_{i}\right]^{12}$

who that Ali not think Fatimah like

'Who does Ali not think that Fatimah likes?'

b. *Kenapa $a_{\mathrm{i}}$ Ali tidak fikir [Fatimah dipecat $\mathrm{t}_{\mathrm{i}}$ ]

why Ali not think Fatimah was fired

'Why did Ali not think Fatimah was fired?'

(12) Ungrammatical Overt Movement from Factive Island

a. *Bagaimana $\mathrm{i}_{\mathrm{i}}$ [kamu gembira [yang Bill belajar $\mathrm{t}_{\mathrm{i}}$ ]] how you happy that Bill studies

'You are happy that Bill studies how?'

b. ??Apa $a_{i}$ yang [kamu gembira [yang Bill belajar $t_{i}$ ]] what that you are happy that Bill studies

'What are you happy that Bill studies?'

While overt wh-movement obeys island constraints, wh-in-situ does not:

(13) Grammatical Wh-In-Situ in Relative Clauses (CNPC)

a. Kamu fikir [Ali suka [perempuan [yang tinggal di mana]]] you think Ali like woman that live at where 'You think Ali likes the woman who lives where?'

b. Kamu sayang [perempuan [yang telah berjumpa siapa]] You love woman that already meet who

'You love the woman who met who?'

(14) Grammatical Wh-In-Situ in Sentential Subject

[Yang Ali mengahwini siapa] mengecewakan ibunya that Ali married who upset his mother 'Who that Ali married upset his mother?'

(15) Grammatical Wh-In-Situ in Adjunct Island Ali dipecat [kerana Fatimah fikir [dia membeli apa]] Ali was fired because Fatimah thinks he bought what 'Ali was fired because Fatimah thinks he bought what?'

(16) Grammatical $W h$-In-Situ in $W h$-Islands ${ }^{13}$

a. Awak agak [di mana [Mary membeli apa]]

Who wonder where Mary bought what

'What do you wonder where Mary bought?'

b. Siapa agak [sama ada Ali ternampak apa] who wonder whether Ali saw what 'What does who wonder whether Ali saw?' (Adapted from Rogayah 1995)

12 It is expected that an argument can be extracted from a weak island such as a negative island but an adjunct cannot. Some informants, on occasion, found (11a) less than perfect, but, as expected, all agreed that it is much better than (11b).

${ }^{13}$ Wh-in-situ in embedded yes/no questions appears to be less well-formed than in embedded $w h$-questions. What is relevant here is that $(16 \mathrm{~b})$ is considerably better than $(10 \mathrm{~b})$, in which overt wh-movement has occurred. 
(17) Grammatical Wh-In-Situ in a Negative Island

?Ali tidak fikir [Fatimah suka siapa]

Ali not think Fatimah like who

'Who does Ali not think that Fatimah likes?'

(18) Grammatical $W h$-In-Situ in a Factive Island

Kamu gembira [yang Bill belajar apa]

you happy that Bill study what

'What are you happy that Bill studies?'

Note that while the Complex NP violations of (13) are compatible with the proposal by Nishigauchi (1990) and others that apparent Subjacency violations are due to massive LF pied-piping, following Nishigauchi's assumptions, the appearance of $w h$-in-situ inside other islands (such as the wh-island) cannot be easily explained by LF pied-piping. We give further arguments against the clausal pied-piping analysis in section 5.4 below. See additional arguments against LF pied-piping in Rogayah (1995).

To summarize, we have shown so far that $w h$-in-situ in Malay, unlike overtly moved $w h$, can occur freely in islands. We shall now show that $w h$-in-situ, in contrast to overtly moved $w h$, does not create $w h$-islands. If it were assumed that the wh-in-situ has undergone covert null operator movement before spellout (as claimed by Watanabe 1993 for Japanese), it would be predicted that $w h$ in-situ creates $w h$-islands for overt movement. Consider first the interaction of relativization and overt $w h$-movement. We assume that relativization in Malay involves movement in the syntax of a null operator to the Spec,CP immediately below the head of the relative clause, as in (19):

$$
\begin{aligned}
& \text { Relative Clause Structure } \\
& {\left[{ }_{N P}[N P]_{i}\left[{ }_{C P} \text { OP }_{i}\left[\text { IP. . } t_{i} \ldots\right]\right]\right.}
\end{aligned}
$$

The sentences of (20) show that overt wh-question movement creates a $w h$-island that blocks relativization:

(20) Relativization out of $W h$-Island Created by Overt $W h$-Movement ${ }^{14}$

\footnotetext{
${ }^{14}$ In (20), one could add a resumptive pronoun, which would "save" the RC from an island violation:

(20') Lelaki $i_{i}\left[\mathrm{OP}_{\mathrm{i}}\right.$ yang [kamu tanya [apa $\mathrm{j}_{\mathrm{j}}\left[\mathrm{dia}\right.$ beli $\left.\left.\left.\left.\mathrm{t}_{\mathrm{j}}\right]\right]\right]\right]$ ialah abang saya.

Man that you ask what he buy is brother my

'The man who you asked (whether) he bought what is my brother.'

Note, crucially, that using resumptive pronouns with RCs can (as is the case in English) improve island violations. We cannot, however, use the resumptive pronoun strategy with wh-questions in Malay:

(i) *Siapai [kamu fikir [Ali nampak [perempuan yang suka $\left.\left.\left.\mathrm{t}_{\mathrm{i}}\right]\right]\right]$

Who you think Ali saw woman who likes

'You think Ali saw woman who likes whom?'

(ii) *Siapai [kamu fikir [Ali nampak [perempuan yang suka $\left.\left.\left.\left\{\begin{array}{c}\text { dia } \\ -n y a\end{array}\right\}\right]\right]\right]$

Who you think Ali saw woman who likes him/her

'You think Ali saw woman who likes whom?'

In general, pronouns are not possible with wh-questions and are also limited with RCs to "saving" relativization into islands. We therefore conclude that Malay (like English) may allow intrusive pronouns (in the sense of Sells 1984) but not true resumptive pronouns.
} 
a. *Orang itu $_{\mathrm{i}}\left[{ }_{\mathrm{CP}} \mathrm{OP}_{\mathrm{i}}\right.$ yang saya tanya $\left[\mathrm{CP}\right.$ di mana $\mathrm{j}_{\mathrm{j}}\left[\mathrm{t}_{\mathrm{i}}\right.$ bekerja $\left.\left.\left.\mathrm{t}_{\mathrm{j}}\right]\right]\right]$ person that that I ask at where work
is brother my

'The person who I asked where he worked is my brother.'

b. *Lelaki $i_{i}\left[O P_{i}\right.$ yang [kamu tanya $\left[\operatorname{apa}_{j}\left[\mathrm{t}_{\mathrm{i}}\right.\right.$ beli $\left.\left.\left.\left.\mathrm{t}_{\mathrm{j}}\right]\right]\right]\right]$ ialah abang saya Man that you ask what buy is brother my

'The man who you asked bought what is my brother.'

In contrast, $w h$-in-situ does not create a $w h$-island:

(21) Relativization into Putative Wh-Island Allegedly Created by Wh-In-Situ (no islandhood)

a. Orang itu $_{\mathrm{i}}\left[\mathrm{OP}_{\mathrm{i}}\right.$ yang saya tanya $\left[\mathrm{t}_{\mathrm{i}}\right.$ bekerja di mana $\left.]\right]$ ialah abang saya

Person that that I ask work at where is brother my 'The person who I asked where he worked is my brother.'

b. Lelaki $i_{i}\left[\mathrm{OP}_{\mathrm{i}}\right.$ yang [kamu tanya $\left[\mathrm{t}_{\mathrm{i}}\right.$ beli apa]]] ialah abang saya man that you ask buy what is brother my 'The man who you asked bought what is my brother.'

Further evidence that covert movement has not applied with wh-in-situ comes from the fact that overt $w h$-movement is grammatical out of a clause with insitu wh:

(22) $\mathrm{Apa}_{\mathrm{i}}$ (yang) kamu fikir [ Ali beli t di mana] what (that) you think Ali bought where 'What do you think Ali bought where?'

To review, examples (7)-(22) indicate that while overt wh-movement displays the usual island properties associated with movement, $w h$-in-situ does not: $w h$-in-situ is neither restricted from occurring in islands nor does it create islands for the movement of other constituents. On the assumption that constraints such as Subjacency (however, they are instantiated from a Minimalist perspective ${ }^{15}$ ) cannot be restricted to a single component (e.g., syntax but not LF), these examples indicate that $w h$-in-situ in Malay does not undergo movement in either the syntax or at LF.

\subsection{The distribution of the meng-prefix}

Examining the distribution of the meng-prefix is a second way to determine whether movement has occurred. The distribution of meng- in Indonesian is described in Saddy (1991, 1992), and seems to be identical to what we have found in Singaporean Malay.

\footnotetext{
${ }^{15}$ Possibly in terms of minimal links. See Manzini (1996) for an attempt to develop a Minimalist account of Subjacency.
} 
Most transitive verbs in Malay optionally take the prefix meng-. ${ }^{16}$ This prefix varies in form depending on the phonological properties of the stem to which it is affixed:

(23) Meng- in Simple Transitive Clauses

a. Guru itu akan (men)-denda Fatimah teacher that will (meng)-punish Fatimah 'The teacher will punish Fatimah.'

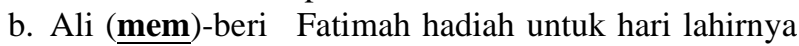
Ali (meng)-give Fatimah present for day birth 'Ali gave Fatimah a present for her birthday.'

On the basis of examples like those of (23), meng- is often taken to be simply a marker of transitivity. However, the possibility of the occurrence of meng- is not determined solely by transitivity, but it is also affected by whether wh-movement has applied over meng- plus verb. When the object of a verb that would otherwise permit the meng-prefix undergoes wh-movement, except in special circumstances that we will not discuss here, the mengprefix cannot occur. But when the subject of a simple sentence is questioned, the appearance of meng- is acceptable:

(24) Subject Question

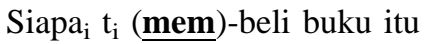
who (meng)-bought book that 'Who bought that book?'

(25) a. Apa Ali $_{\text {(*mem)}}$ )-beri t $\mathrm{t}_{\mathrm{i}}$ pada Fatimah What Ali (*meng)-gave to Fatimah 'What did Ali give to Fatimah?'

b. Buku $u_{i}$ mana Fatimah (*mem)-beli $t_{i}$ book which Fatimah (*meng)-buy

'Which book did Fatimah buy?'

In contrast to the examples of (24-25), when the wh-moved element is not an NP, the loss of meng- does not occur:

(26) Meng- Not Lost When Non-NP Wh-Moved

a. Kenapa $\mathrm{K}_{\mathrm{i}}$ Mary ( $\underline{\mathbf{m e m}}$ )-beli buku itu $\mathrm{t}_{\mathrm{i}}$ Why Mary (meng)-bought book that 'Why did Mary (meng)-buy that book?'

16 The appearance of meng- is optional in the speech of our informants and in colloquial Malay in general. In highly colloquial speech verbal prefixes are usually omitted. Thus, the grammar of colloquial Malay must characterize when meng- is possible and when it is not, whereas in formal Malay and Indonesian, the grammar must characterize when a representation is ill-formed if meng- does not appear. 


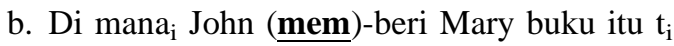
at where John ( 'Where did John give Mary that book?'

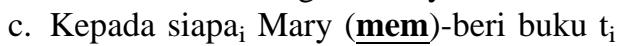
to who Mary (meng)-give book

'To whom did Mary give a book?'

In (26a) the wh-word is an adverb and meng- can appear. Similarly, in (26b) and (26c), the $w h$-form is a prepositional phrase. Again, meng-is permitted. Note that the wh-prepositional phrase in (26c) kepada siapa is an argument of the verb while in (26a) and (26b) the $w h$-form is an adjunct. Thus, the loss of meng- is determined by whether the $w h$-form is an NP, and not by whether it is an argument or an adjunct.

The disappearance of meng- occurs not only when an object NP is extracted, but also when a complement subject is extracted over a verb normally permitting meng-:

(27) Meng- Lost When Complement Subject Extracted

a. Siapa ${ }_{i}$ Bill (*mem)-beritahu ibunya [yang $t_{i}(\underline{\text { men }})$-yintai Fatimah] who Bill (meng)-tell mother his that (meng)-love Fatimah

'Who does Bill tell his mother that loves Fatimah?'

b. Siapa ${ }_{i}\left({ }^{*}\right.$ mem $)$-buktikan [yang $t_{i}$ (men)-curi kereta] who Ali (meng)-prove that (meng)-steal car 'Who did Ali prove stole the car?'

Note that although meng- cannot occur between the extraction site for $w h$ and its landing site, meng- can occur below the extraction site. Thus, the appearance of meng- on the complement verbs in (27) is well-formed. ${ }^{17}$

Finally, the loss of meng- is not restricted to wh-questions. Rather, it also occurs in object preposing constructions and in relative clause formation and focus movement. The loss of meng- in object preposing is illustrated in (28).

(28) Loss of Meng- in Object Preposing

a. Buku itui adik saya (*mem)-beli ti

Book that brother my (meng)-buy

'My brother bought that book./That book was bought by my

brother.'

b. Ali $i_{i}$ saya (*men)-cubit $\mathrm{t}_{\mathrm{i}}$

Ali I (meng)-pinch

'I pinched Ali./Ali was pinched by me.'

Although object preposing would appear at first glance to be movement to an A-position, there are convincing arguments that the preposed NP is in an

${ }^{17}$ Examples like (27) show that the loss of meng- in (25) cannot be due to main clause object preposing, or "affixless" passivization. Note that siapa in (27) originates after the complementizer yang in the complement clause. This is not a position from which object preposing is possible. 
A-position, and that object preposing, like passivization, involves the movement of an object to the specifier of IP. For example, the preposed NP can be PRO in control constructions and can undergo raising. See Chung (1994), Alsagoff (1992), and Guilfoyle et al (1992).

Meng- is also lost when an object or complement subject is relativized or undergoes focus movement, both of which appear to involve the movement of a null operator. These facts are illustrated in (29) and (30):

(29) Loss of Meng- in Relativization

a. $\left[\mathrm{Buku}_{\mathrm{i}}\left[\mathrm{OP}_{\mathrm{i}}\right.\right.$ yang $\left[\mathrm{John}\left({ }^{*} \mathrm{mem}\right)\right.$-beli $\left.\left.\mathrm{t}_{\mathrm{i}}\right]\right]$ itu] menarik Book that John (meng)-buy that interesting 'That book that John bought is interesting.'

b. $\left[\right.$ Lelaki $_{i}\left[\mathrm{OP}_{\mathrm{i}}\right.$ yang $\left[\mathrm{t}_{\mathrm{i}}(\underline{\mathbf{m e m}})\right.$-beli buku itu $\left.\left.]\right]\right]$ adik saya Man that (meng)-buy book that brother my

'The man who bought that book is my brother.'

(30) Focus Movement ${ }^{18}$

a. Buku ini ${ }_{i}\left[\mathrm{OP}_{\mathrm{i}}\right.$ yang [Fatimah (*mem)-beli $\left.\left.\mathrm{t}_{\mathrm{i}}\right]\right]$

Book this that Fatimah (meng)-buy

'This is the book that Fatimah bought.'

b. Fatimah $\left[\mathrm{OP}_{\mathrm{i}}\right.$ yang [Ali (*men)-cintai $\left.\left.\mathrm{t}_{\mathrm{i}}\right]\right]$

Fatimah that Ali (meng)-love

'It's Fatimah who Ali loves.'

The environments in which meng- is lost in relative clauses and focus movement are the same as those in which it is lost in wh-questions. For reasons of space, however, we shall not provide the full range of environments in which the prefix is lost for these constructions. These examples are given to illustrate the fact that the loss of meng- occurs in instances of null operator movement before spell-out just as it does when a wh-question-word undergoes overt movement before spell-out.

To summarize, the obligatory omission of meng- with verbs that would otherwise permit meng- indicates the movement of an NP argument over the meng- + verb. Next consider (31); in such cases of $w h$-in-situ, in contrast to questions involving overt movement and to null operator movement, mengappears freely:

a. Wh-In-Situ Questioning Object

Ali (mem)-beri Fatimah apa?

Ali (meng)-give Fatimah what

'What did Ali give Fatimah?'

${ }^{18}$ A possible structure for so-called focus movement sentences might be:

(i) [CP [IP [buku ini] BE [DP [CP $\mathrm{OP}_{\mathrm{i}}$ yang [IP Fatimah beli $\left.\left.\left.\left.\mathrm{t}_{\mathrm{i}}\right]\right]\right]\right]$

book this that Fatimah buy

See Kader (1976) and Alsagoff (1992) for related analyses and discussion of this construction. 
b. Wh-In-Situ Questioning Object

Bill fikir Ali menyintai / cintai siapa?

Bill think Ali (meng)-love who

'Who does Bill think Ali loves?'

c. Wh-In-Situ Questioning Object

Mary ( $\underline{\text { mem })-b e l i ~ b u a h ~ a p a ~ d i ~ k e d a i ? ~}$

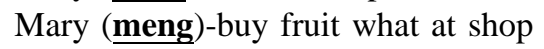

'What fruit did Mary buy at the shop?'

d. Wh-In-Situ Questioning Complement Subject

Mary ( $\underline{\text { mem })-b e r i t a h u ~ a w a k ~ y a n g ~ s i a p a ~(\underline{m e})-l i h a t ~ F a t i m a h ? ~}$

Mary (meng)-inform you that who (meng)-see Fatimah

'Mary informed you that who saw Fatimah?'

Thus, the distribution of meng-provides confirmation that movement is only involved in the derivation of overtly moved $w h$, and not in the case of $w h$-insitu. ${ }^{19}$ We will argue below that $w h$-in-situ always involves unselective binding in Malay, and, hence does not involve movement. ${ }^{20}$

19 Chung (1994) provides an analysis of wh-agreement in Chamorro (a Western Austronesian language) as agreement between the Case of the wh-trace and V, affecting the morphology of $\mathrm{V}$ (rather than as a manifestation of Spec-head agreement with $\mathrm{C}^{0}$ ). This is very similar to what happens in Malay when meng- is omitted, since wh-movement and also covert OP movement affect the morphology of the verb rather than the form of Comp. In work in progress, we hope to argue that the correct treatment for meng- is along the lines proposed by Chung for $w h$-agreement in Chamorro.

${ }^{20}$ Data involving weak crossover may at first glance seem to pose a problem for an account of wh-in-situ without movement at LF. Even though it is claimed in Saddy (1991) that there is no Weak Crossover effect with wh-in-situ in Malay, our Malay informants consistently reject equivalent sentences:

(i) *Prof dia $a_{i}$ fikir saya menyintai siapa $a_{i}$ ?

Prof his think I love who

His prof thinks I love who? (his=siapa)

Rogayah (1995) also claims that Weak Crossover holds for wh-in-situ. We therefore assume that Weak Crossover applies to $w h$-in-situ in Malay.

It should be noted, however, that Weak Crossover is generally analyzed as a constraint against certain representations rather than a constraint on movement itself. The ungrammaticality of (i) can be ascribed to a Bijection violation: two variables are bound by a single quantifier (Koopman \& Sportiche 1982). This analysis, like other treatments of Weak Crossover, is not phrased derivationally as a constraint on movement, but rather representationally as a constraint against the existence, presumably at LF, of an operator that binds more than one variable:

(ii) Weak Crossover Structure

$\left[\right.$ Operator $_{\mathrm{x}}[\ldots(\mathrm{x}) \ldots(\mathrm{x}) \ldots .]$.

This structure might arise by movement, as in overt $w h$-movement structures (resulting in: $\left[w h_{\mathrm{i}}\left[\ldots\right.\right.$ Pronoun $\left.\left.\left._{\mathrm{i}} \ldots \mathrm{t}_{\mathrm{i}}\right]\right]\right)$, but it might also be the direct result of merger, as is the case for Unselective Binding, which yields the following structure for (i), where OP is a base-generated operator and NP is a base generated NP variable:

(iii) Unselective Binding configuration for (i):

[Operator $_{\mathrm{i}}\left[\ldots\right.$ Pronoun $\left._{\mathrm{i}} \ldots w h_{\mathrm{i}}\right]$

Since Unselective Binding, just like movement, can yield a structure that is subject to the Bijection Condition, there is no reason to view the Weak Crossover facts as an argument in favor of movement in the $w h$-in-situ examples. Rather, we conclude that Weak Crossover must be configurational in nature. What remains a mystery under this account, however, is why cases of "donkey" anaphora are not ill formed, since in these sentences the existential operator unselectively binds both a quantifier and a pronoun, as discussed in (Heim 1982):

(iii) Every [man who owns a donkey] beats it. 


\section{Distributional Properties of Partially Moved Wh}

We shall now turn to partially moved $w h$-questions, and examine their properties with respect to islandhood and the possibility of the meng-prefix.

\subsection{Islandhood and partially moved wh}

As would be expected, partially moved wh cannot move overtly out of an island. Compare (32), in which the $w h$-word remains in-situ within a relative clause, and (33), in which the $w h$-word is moved out of the relative clause, but not to full scopal position.

(32) Wh-Word In-Situ in Relative Clause

Ali memberitahu kamu [yang dia (mem)baca [buku [yang tentang apa]]] Ali told you that he read book that about what

'Ali told you that he read a book that was about what?'

(33) Wh-Word Moved From Relative Clause By Partial Movement

*Ali memberitahu kamu [apa $\mathrm{i}_{\mathrm{i}}$ yang [ Mari fikir [dia suka perempuan

[yang [ beli $t_{i}$ ]]]]]

Ali told you what that Mari think he likes woman

that buy

'What did Ali tell you that Mary thinks that he likes a woman who

bought?'

Surprisingly, however, as was first noted by Saddy (1991) for Indonesian, not only is partial movement subject to Subjacency when the $w h$-form moves overtly out of an island, but Subjacency also applies when an island boundary intervenes between the surface position of the partially moved $w h$-word and the specifier of CP representing the scope of the wh-word:

(34) Wh-In-Situ in Relative Clause

a. Kamu sayang [perempuan yang Ali fikir [yang telah berjumpa

You love woman that Ali thinks that already meet who

'You love the woman who Ali thinks met who?'

b. Kamu sayang [perempuan yang Ali fikir [yang telah makan apa]]

You love woman that Ali thinks that already eat what

'You love the woman who Ali thinks ate what?'

(35) Wh Partially Moved Within Relative Clause

a. *Kamu sayang [perempuan yang Ali fikir [(dengan) siapa $a_{i}$ yang telah jumpa $\left.\left.t_{i}\right]\right]$

You love woman that Ali thinks (with) who that

'You love the woman who Ali thinks met who?' already meet

b. *Kamu sayang [perempuan yang Ali fikir [apa $a_{i}$ yang telah makan $t_{i}$ ]] You love woman that Ali thinks what that already eat 'You love the woman who Ali thinks ate what?' 
In (34) and (35), the $w h$-word remains within the relative clause and no overt movement out of the relative clause has occurred, yet an island violation is found. These sentences are in sharp contrast with wh-in-situ ((34) and (35)), in which an unmoved $w h$-word appears with impunity inside a relative clause. $^{21}$ On the assumption that sensitivity to islands is indicative of movement, examples like (34) and (35) lead to the conclusion, reached previously by Saddy (1991), that partially moved $w h$ involves not only overt syntactic movement of the $w h$-word, but also covert movement to scopal position. Thus, partially moved $w h$ contrasts with $w h$-in-situ: in the case of wh-in-situ, evidence from islands shows that these forms undergo no covert movement, but island evidence suggests that partially moved $w h$ undergoes covert movement from the surface position of $w h$ to scopal position. We will further illustrate this with both strong and weak islands.

(36) Wh Partially Moved from Subject Island

*Sungguh menghairankan [apakah ${ }_{i}$ yang Mary beli $t_{i}$ di JB] very surprising what that Mary bought in JB

'What is it that is very surprising that Mary bought in JB?'

(37) Wh Partially Moved from Adjunct Island ${ }^{22}$

a. *Ali dipecat [apa $\mathrm{a}_{\mathrm{i}}$ (yang) kerana dia beli $\mathrm{t}_{\mathrm{i}}$ ]

Ali was fired what (that) because he bought

'Ali was fired because he bought what?'

(38) Wh Partially Moved from Wh-Island ${ }^{23}$

*Di mana ${ }_{j}$ kamu fikir [apa $a_{i}$ (yang) Ali beli $t_{i} t_{j}$ ]

at where you think what (that) Ali buy

'Where do you think what did Ali buy?'

(39) Wh Partially Moved from Factive Island

*Kamu gembira [bagaimana ${ }_{\mathrm{i}}$ yang Bill belajar $\mathrm{t}_{\mathrm{i}}$ ]

you happy how that Bill study

'You are happy that Bill studies how?'

21 Our informants noted that having two yang complementizers slightly degrades the sentences in (34), but the sentences are grammatically correct. In contrast, the examples in (35) are strongly ungrammatical.

22 Note that the sentence is just as bad if the adjunct clause marker kerana 'because' precedes the partially moved $w h$ :

(i) *Ali dipecat [ kerana apa $a_{i}$ (yang) dia beli $\mathrm{t}_{\mathrm{i}}$ ]?

Ali was fired because what (that) he bought

'Ali was fired because he bought what?'

(This sentence does have an irrelevant grammatical reading in which apa yang dia beli is a headless relative clause: 'He was fired because of what he bought.')

23 This sentence contrasts with the following sentence, in which no islands are created by the moved $w h$ for the $w h$-in-situ.

(i) Kamu fikir [apa $a_{i}$ yang Ali beli $t_{i}$ di mana]

you think what that Ali buy where

'What do you think Ali bought where?' 
(40) Wh Partially Moved from Negative Island ${ }^{24}$

a. *Ali tidak fikir [siapa $\mathrm{i}_{\mathrm{i}}$ (yang) Fatimah suka $\mathrm{t}_{\mathrm{i}}$ ]

Ali not think who (that) Fatimah like

'Who doesn't Ali think that Fatimah likes?'

b. *Ali tidak bilang [apa $\mathrm{a}_{\mathrm{i}}$ (yang)Fatimah beli $\mathrm{t}_{\mathrm{i}}$ ]

Ali not reveal what (that) Fatimah bought

'What did Ali not reveal that Fatimah bought?'

To summarize, no islands can appear between the partially moved $w h$ and the scopal position in which the wh-OP is interpreted in the main clause. These facts will be accounted for in section 5. We claim there that these facts are evidence for post-spell-out movement of the wh-OP to scopal position.

\subsection{Meng-omission and partially moved wh}

We shall now examine whether the distribution of meng-corroborates the conclusion based on islandhood that partially moved wh undergoes further, covert movement. Recall that overt movement of a $w h$ argument NP or NP operator requires the omission of meng-, but meng-omission is not required for $w h$-in-situ. When partial movement occurs, meng-cannot appear in the domain over which the wh-phrase has moved overtly, but the prefix can appear above the overt landing site of the $w h$-form:

(41) Non-Omission of Meng- with Partially Moved Wh

Ali ( $\underline{\text { mem)})-b e r i t a h u ~ k a m u ~ t a d i ~[a p a ~} a_{i}$ yang Fatimah (*mem)-baca $t_{i}$ ]

Ali (meng)-told you just now what that Fatimah (meng)-read

'What did Ali tell you just now that Fatimah was reading?'

In (41) meng- must be omitted below the surface position of apa, but not between apa and its scopal position. Thus, the distribution of mengcontradicts the islandhood facts. The islandhood facts treat apa as though it were moved to scopal position, but the distribution of meng- treats apa as though further movement from the intermediate specifier of $\mathrm{CP}$ to scopal position did not occur. In section 5, we will provide an explanation for the apparent contradiction between the island facts and the meng-deletion facts.

\section{A Minimalist Analysis of Malay Wh}

The data presented in sections $2-4$ raise the following four questions in the context of the Minimalist Program:

a. How can seemingly "optional" wh-movement be accounted for in a deterministic account of grammar like the Minimalist Program? Specifically, in this theoretical context, what permits the existence of

\footnotetext{
24 The sentences of (40) are ungrammatical because LF movement from the PM site to scopal Spec,CP is subject to antecedent government. See Rizzi (1992).
} 
full movement, in-situ, and partial movement in the same language (or across languages)?

b. What can account for the lack of islandhood facts with wh-in-situ in Malay?

c. How can the ungrammaticality of $w h$-in-situ with adverbial adjuncts in Malay be accounted for?

d. Regarding Partial Movement in Malay, what accounts for the asymmetry between the islandhood facts and the distribution of meng-? ${ }^{25}$

We shall try to provide answers to these questions in the analysis that follows.

\subsection{Critical components of our analysis}

Our analysis is based on the following critical assumptions:

1. Following Cheng (1991), Aoun \& Li (1993), Watanabe (1993), and Tsai (1994), we assume that the question operator is universally generated as a null operator and that the $w h$-form is universally a variable. Languages, however, differ with respect to whether or not the operator and the variable are joined in the lexicon into a single word. While in English the OP and the variable are lexicalized as a single word, in Chinese, for instance, the question word is a variable that can be bound by a phonologically null question operator.

There are two kinds of evidence that have been used to argue that question words in Chinese are variables rather than operators. First, as was shown by Cheng \& Huang (1996), in Chinese bare conditionals, question words appear to be prima facie variables:

(42) Chinese Bare Conditional

Shei xian lai, shei jiu xian chi.

who first comes who then first eats

'If $x$ comes first, $x$ eats first.'

Cheng \& Huang argue that in the logical form of (42), the position occupied by shei is clearly that of a bound variable (bound by a phonologically null universal quantifier):

(43) for all $(x)$ ( $x$ comes first $\rightarrow x$ eats first)

Second, it is predicted that in languages like Chinese, wh-words are used in a variety of non-question functions appropriate to a bound variable (Aoun \& Li 1993 inter alia):

${ }^{25}$ We leave unanswered in this paper the more general question of why partial $w h$-movement should occur at all, given a Minimalist conception of grammar, in which $w h$-movement in the syntax is motivated by the need to satisfy the checking requirements of STRONG Q-features. See Horvath (1997), Turano (1995), and Hermon \& Cole (in preparation) where we discuss this issue both for Malay and for other languages. 
(44) Wo shenme dou bu zhidao.

I what all not know

'I don't know anything.'

In (44) the question word shenme 'what' does not have an interrogative meaning, but rather receives its interpretation from dou 'all'. It is predicted that question words as variables bound by non-interrogative operators will not be found in languages like English, in which the operator and the variable are combined in the lexicon.

Returning to Malay, we will claim that Malay differs from both Chinese and English in allowing two options with regard to the combination of the $w h$-variable and the operator as a lexical item:

(45) a. Option One: An OP appears in the lexicon as a single entry with the $w h$-word (the variable), thereby forcing movement of the $w h$-word with the OP;

b. Option Two: An OP is generated separately from the $w h$-word, with the $w h$-word acting as a variable bound by OP.

The fact that $w h$-words in Malay can undergo overt movement constitutes ipso facto evidence that OP and the $w h$-word can be combined into a single word in Malay. Empirical support for the claim that in Malay wh-words can also be variables separate from the question operator is provided by the fact that $w h$-words can be used as variables bound by non-wh-operators:

(46) Use of Apa 'What' as a Variable

a. Dia tidak membeli apa-apa untuk saya.

he not MENG-buy what-what for me

'He did not buy anything for me.'

b. Dia tidak membeli apa-pun untuk saya.

he not MENG-buy what-also for me

'He did not buy anything for me.'

(47) Use of Siapa 'Who' as a Variable

a. Saya tidak kenal siapa-siapa di universiti itu.

I not recognize who-who at university that

'I didn't recognize anyone at that university.'

b. Saya tidak kenal siapa-pun di universiti itu.

I not recognize who-also at university that

'I didn't recognize anyone at that university.'

(48) Use of Mana 'Where' as a Variable

a. Awak tidak pergi ke mana-mana.

you not go to where-where

'You didn't go anywhere.'

b. Awak tidak pergi ke mana-pun.

you not go to where-also

'You didn't go anywhere.' 
In the (a) examples of (46)-(48), the variable is bound by the existential quantifier represented overtly by the reduplication of the question word. Similarly, in the (b) sentences, the variable is bound by the existential quantifier represented by -pun 'also'. These examples show that in Malay, like Chinese, question words can be variables bound by an operator other than $w h .^{26}$

2. On the basis of the facts presented earlier, and following ideas in Tsai (1994), Reinhart (1993, 1995), and Cole \& Hermon (1995), we assume that in $w h$-in-situ in Malay the (wh-OP) question operator is merged at the root Spec $\mathrm{CP}$, and, therefore, unselectively binds a $w h$-variable in its scope. As was noted, unselective binding does not involve movement (not even at LF). Furthermore, as argued by Reinhart (1993), Tsai (1994), and others, wh-adverbials cannot be bound by unselective binding, and hence are forced to move. ${ }^{27}$ The differing

26 As noted by an anonymous reviewer, the evidence that question words are variables in Malay is not as strong as the evidence in Chinese. In Malay, the bare wh-word does not act as an indefinite without adding the morpheme -pun or reduplication. Note that this is similar to the situation in Japanese, a language in which $w h$-words have been analyzed as variables. In Japanese, an indefinite NP can be derived from a wh-word by adding a suffix: dare 'who' is given the interpretation of an indefinite by adding the suffix - $k a$ and forming dareka 'someone'. Also, the suffix -mo can be used to form daremo 'anyone' or 'everyone', as described in Nishigauchi (1990) and Tsai (1994) inter alia.

Moreover, we do not claim that the $w h$ is a pure variable in every language in which a word can be related to an indefinite. Thus, in German adding the prefix irgend derives indefinites from wh-words: irgendwer 'someone', irgendwo 'somewhere'. The same is true in Hungarian: we can add vala 'some' to $k i$ 'who' or mit 'what' to form indefinites. However, in these languages movement of $w h$ is obligatory. We claim that in these languages (just as in English 'somewhere' and 'somewhat') the $w h$-variable is combined with a null (wh) or overt (existential) operator in the lexicon, forcing overt $w h$-movement due to pied-piping of the overt lexical material.

A more serious problem for our analysis is found in languages in which $w h$-words are clearly variables but in which wh-movement is obligatory. According to Aissen (1996), in Tzotzil (a VOS language) $w h$-words are variables, since they can be used as both interrogatives and indefinites. However, as distinct from Malay and Chinese, all $w h$-words and focused constituents have to move to the left, to a preverbal position. If they remain in-situ, the $w h$ can only be interpreted as a free-choice $w h$ (meaning roughly 'anyone', 'anything', 'anywhere'...). We would have to claim that what forces $w h$-movement in a language like Tzotzil is not the need to check strong $w h$-features in Spec of $\mathrm{C}$ (since the strong feature could be checked by a Q operator merged to Spec, $\mathrm{CP}$, given the fact that Tzotzil, like Malay, has a variable type wh), but an independent constraint that forces movement of focused constituents to a preverbal position. No focused constituents (whether operators or variables) can stay in a postverbal position.

Another type of potential problem for our account comes from languages like Turkish, which allow $w h$-in-situ but do not seem to allow $w h$-words to be used as indefinites (Jaklin Kornfilt, p.c.). In Turkish there is no overt evidence for a variable analysis for $w h$. This may indicate that languages can have additional constraints which prevent overt $w h$-movement and "force" $w h$-insitu even for operator type $w h$. For example, it is argued in Kayne (1994) that pure OV languages prohibit wh-movement to Spec of $\mathrm{CP}$, due to the fact that this position is already filled by the leftward movement of the IP in OV languages.

27 Reinhart $(1993,1995)$ argues on semantic grounds that apparent unselective binding involves the binding of the variable of a choice function. The choice function picks out an individual member of a set defined by the nominal restrictor. This can only occur in the case of nominal $w h$. Thus, adverbial $w h$ cannot be interpreted in-situ. Since it does not affect the issues under consideration in this paper, we will maintain the pretense that the question operator binds the $w h$-variable directly rather than through the mediation of a choice function, and shall continue to employ the term "unselective binding." 
properties of $w h$-nominals and adverbials will be seen to follow from the inability of adverbials to be bound by unselective binding. Note that whether an adverb is forced to move overtly (as in Malay) or at LF (as in Chinese) must be determined by whether the adverb is a merged OP+variable form (as claimed for Malay below) or a nonmerged OP...VAR (as we claim is the case in Chinese in section 6.1).

3. When two competing derivations both converge, following Chomsky (1995), we assume that the more economical derivation will block the less economical. We make use of the following economy principle:

(49) Economy: A converging derivation that does not employ Move is more economical than a derivation (based on the same numeration) that does employ Move.

4. Overt $w h$-movement is motivated by the need to discharge the STRONG wh-features of an interrogative complementizer (Q). We shall assume that $\mathrm{Q}$ is STRONG universally and argue that the range of variation in wh-movement across languages can be accounted for without the need to posit variation in the strength of $\mathrm{Q}$.

5. At LF, wh-questions have an operator-variable structure that, we have argued, is due to the variable Binding Condition:

$$
\mathrm{OP} x[\ldots x \ldots]
$$

This is an output condition on the grammar and is a corollary of FI. If the structure in (50) does not obtain by LF, wh will move to scopal Spec,CP in order to create this structure. ${ }^{28}$

\subsection{Predictions of the analysis}

The analytic options possible for Malay in our system are summarized for $w h$-NPs in Table (51). We shall discuss $w h$-adverbs in section 5.3. The first column shows the construction type under consideration (full movement or $w h$-in-situ). The second column shows the feature content of the matrix $Q$ (invariably STRONG). When OP occurs in the second column, it indicates that the operator has been merged at scopal Q (i.e., base-generated at Q rather than moved to that position). The third column indicates whether the $w h$ word is combined OP+VAR or whether OP is inserted separately (OP...VAR). The fourth column shows the consequences of the option chosen with regard to whether movement occurs, whether islandhood is respected and whether meng- is obligatorily omitted. The options in boldface are the actual options found in Malay. We shall see that the five critical

\footnotetext{
${ }^{28}$ As mentioned in fn. 2, an alternative to the Variable Binding Condition is the requirement that expletives be eliminated from the representation by LF. Our data does not distinguish between these two possibilities. It should be noted, however, that both LF Expletive Replacement and the Variable Binding Condition claim that movement can be motivated by the need to satisfy the requirements of FI.
} 
components of our analysis outlined in section 5.1 allow the analysis to predict correctly which options are in fact instantiated in the language.

(51) Summary of Malay Options for Wh-NPs

\begin{tabular}{llll}
\hline $\begin{array}{l}\text { Construction } \\
\text { Type }\end{array}$ & $\begin{array}{l}\text { Features on } \\
\text { Matrix Q }\end{array}$ & $\begin{array}{l}\text { Type of } \\
\text { wh-word }\end{array}$ & Consequences \\
\hline a. full movement & STRONG Q & [OP+VAR] & $\begin{array}{l}\text { Overt movement; } \\
\text { all islands; } \\
\text { meng- deletion }\end{array}$ \\
\hline b. in-situ & STRONG Q & & $\begin{array}{l}\text { Unselective Binding; } \\
\text { no islands; } \\
\text { no meng-deletion }\end{array}$ \\
\hline c. in-situ & STRONG Q & [OP...VAR] $]$ & $\begin{array}{l}\text { OP movement; } \\
\text { all islands; } \\
\text { meng- deletion }\end{array}$ \\
& & &
\end{tabular}

Consider now the predictions made with regard to each option. Derivations are in competition when they are based on the same numeration (roughly, the same words). Derivations (b) and (c) are based on the same numeration and therefore compete if both converge. Derivation (a) contains a different question word (OP+VAR) from that found in (b) and (c) (VAR). Thus, (a) is not in competition with either (b) or (c). ${ }^{29}$

All three derivations converge. Since (a) is not in competition with any other derivation, economy factors do not enter into the evaluation of the derivation and the sentence is well-formed. Both derivations (b) and (c) converge, and, as was seen, are in competition with each other. Since (b) does not involve movement and (c) does, (b) is more economical than (c), and (c) is blocked. Thus, (51) predicts that full movement and unselective binding will be possible for $w h$-NPs in Malay, but covert $w h$-movement will not. This analysis thereby makes the correct prediction that wh-in-situ in Malay will not respect islands and will not result in meng-deletion. ${ }^{30}$

\footnotetext{
29 It is crucial for our analysis that all and only converging derivations formed from the same numeration are in competition (per Chomsky 1995). In particular, we cannot allow competition between questions based on numerations that differ only in that in one derivation the question word is OP+VAR and in the other it is VAR alone. These cannot be viewed as competing despite the fact that these sentences may receive identical semantic interpretations. If all derivations receiving the same interpretation were to compete, (51a) would compete with (51b), and movement would be ruled out as uneconomical. Thus, such an approach would incorrectly predict that overt wh-movement is not possible in Malay. For discussion of what should count as competing derivations, see Reinhart (1995).

30 As noted by an anonymous reviewer, in the dialect we are reporting on it is hard to rule out (51c) empirically, since meng-, in general, is optional. It could therefore be the case, that option (c) exists in addition to option (b), even though it leads to ungrammaticality when an in-situ $w h$
} 


\subsection{The ungrammaticality of in-situ adverbial wh}

Turning now to $w h$-adverbs, following Reinhart (1993) and Tsai (1994), we assume that unselective binding is not possible for adverbial $w h$-words. Given this assumption, we consider the possible derivations for adverbial $w h$, and will provide an answer to why Malay does not have adverbial $w h$-in-situ:

(52) Malay Options for Wh-Adverbs

\begin{tabular}{llll}
\hline $\begin{array}{l}\text { Construction } \\
\text { Type }\end{array}$ & $\begin{array}{l}\text { Features on } \\
\text { Matrix Q }\end{array}$ & $\begin{array}{l}\text { Original } \\
\boldsymbol{w h} \text {-site }\end{array}$ & Consequences \\
\hline a. full movement & STRONG Q & [OP+VAR] & $\begin{array}{l}\text { overt movement; } \\
\text { all islands }\end{array}$ \\
\hline b. in-situ & WEAK Q & {$[\mathrm{OP}+$ VAR] $]$} & $\begin{array}{l}\text { LF OP movement; } \\
\text { all islands; } \\
\text { adverb in-situ }\end{array}$ \\
\hline c. in-situ & STRONG Q & $\ldots$ VAR] & $\begin{array}{l}\text { Unselective Binding; } \\
\text { no islands }\end{array}$ \\
\hline d. in-situ & STRONG Q & {$[\mathrm{OP} . . . \mathrm{VAR}]$} & $\begin{array}{l}\text { OP movement; } \\
\text { all islands }\end{array}$ \\
\hline
\end{tabular}

By hypothesis, the $w h$-feature of $\mathrm{Q}$ is strong, so derivation (b) is ruled out. Furthermore, since unselective binding is not possible for wh-adverbials, derivation (c) is impossible as well. This leaves derivation (a) and (d) as wellformed with respect to the principles of UG.

In fact, (a) occurs in Malay while (d) does not. Since (d) is not ruled out by principles of UG, the ungrammaticality of the derivation must be due to a property specific to Malay. This must be a lexical fact about the language rather than a grammatical "parameter" since we assume that grammatical principles are invariant. We, therefore, propose as a fact about the Malay lexicon that $w h$-adverbials, unlike $w h$-NPs, are invariably OP+VAR, and never VAR alone.

There is, in fact, independent evidence in favor of this claim. If $w h$ adverbials are never VAR alone, it is predicted that $w h$-adverbials in Malay can never receive a non-interrogative interpretation; i.e., they can never be bound by an operator other than the interrogative operator. This prediction is correct. Compare $w h$-adverbials in (53)-(54) with $w h$-NPs in (46)-(48):

\footnotetext{
happens to be inside an island. In formal Malay, however, a dialect in which meng- is obligatory whenever it is possible, option (c) can easily be ruled out, since in this dialect speakers require a meng-prefix on the verb in an in-situ wh-question. (51c) falsely predicts that the absence of meng- would be possible in formal Malay in wh-in-situ.
} 
(53) a. *Siti tak pukul anaknya kenapa-kenapa.

Siti not hit child-3psg why-why

'Siti did not hit her child for any reason.'

b. *Siti tak pukul anaknya kenapa-pun.

Siti not hit child-3psg why-also

'Siti did not hit her child for any reason.'

(54) a. *Saya tak boleh belajar bagaimana-bagaimana.

I not can study how-how

'I cannot study for any reason.'

b. *Saya tak boleh belajar bagaimana-pun.

I not can study how-also

'I cannot study for any reason.'

These examples show that $w h$-adverbials in Malay cannot be bound by noninterrogative operators. Thus, we conclude that derivation (d) is ruled out by the fact that the Malay lexicon lacks an entry in which kenapa 'why' or bagaimana 'how' appears as a variable.

It should be noted that unlike Tsai (1994), we do not claim that the requirement that $w h$-adverbials are $\mathrm{OP}+\mathrm{VAR}$ is due to principles of UG. Rather, we shall argue in section 6.1 (pace Tsai) that adverbial $w h$-variables that are not lexically combined with an OP do occur in Chinese, with the result that in-situ $w h$ for adverbials is possible in Chinese. However, even in Chinese $w h$-adverbs (unlike $w h$-nouns) cannot appear inside islands. This restriction is due to a difference in semantic type between wh-nouns and adverbs; as discussed in 6.1, a question operator can unselectively bind only variables that range over individuals, but not those that range over propositions. Since unselective binding is not available for the adverb $w h$ variables in Chinese, the OP associated with the variable has to move to scopal Spec,CP at spell-out, causing island violations.

\subsection{Alternative analyses: Chains with multiple spell-out and clausal pied-piping}

In Chomsky (1995) it is proposed that overt (pre-spell-out) wh-movement is driven only by the need to check formal features. Since we have been assuming that Q-features are universally strong, it might be taken to follow that in all languages $w h$-features are moved to Spec, $\mathrm{CP}$ creating a chain before spell-out. The issue then would be whether the head of the chain is spelled out, presumably due to the pied-piping of lexical material together with the $w h$-feature, or whether the $w h$-word is spelled out at the original site. Following this line of thought, it might be proposed that languages like Malay differ from English only in specifying that it is the tail of the chain that is spelled out rather than the head, thus giving the impression of $w h$-in-situ while in fact movement has occurred.

Clearly, any such theory will have to account for why some languages force spell-out at the head of the chain, while others allow the tail to be 
spelled out. But setting this issue aside, let us consider the empirical predictions of such an analysis.

Given that even in chains in which the tail is spelled out, there is movement involved (of the $w h$-feature) it would be predicted that all island effects should be found between the head and the tail of the chain. In addition, since we have assumed that meng- deletion is due to chain creation, this effect should be observed as well. As we have shown, however, Malay does allow $w h$-in-situ inside islands and does not exhibit meng- deletion in insitu sentences. Thus the simple version of the chain account with multiple spell-out options cannot account for the data.

There is however a more complex account of $w h$-movement as copying that, combined with a pied-piping account, gives the appearance of being able to handle the data (see Groat \& O'Neil 1996). We will refer to this analysis as the "Multiple Spell-out" account. We shall argue, however, that the Multiple Spell-out account is also less adequate than the analysis presented in sections 5.1-5.3. In the Multiple Spell-out account, overt movement is movement that carries phonological features to the head of the chain, while covert movement is feature movement which leaves phonological material behind (in effect, forcing spell-out of the tail of the chain). In such a system, languages with overt $w h$-movement and languages with $w h$-in-situ both have $w h$-chains and there is no difference in the timing of movement with respect to spell-out. The only difference is where the category is pronounced. Groat \& O'Neil also assume that strong features can only be checked in a checking relation with a node specified for phonological features: i.e., strong features will force category movement, while weak features will not force category movement, resulting in feature movement with the tail of the chain being spelled out (i.e., in-situ $w h$.

For example, Groat \& O'Neil (1996) suggest that since $w h$-features are weak in Japanese, $w h$-movement does not result in copying phonological features to Spec,CP. In addition, to explain the lack of Subjacency effects in complex DPs in Japanese, their account needs to assume that the entire phrase is pied-piped to Spec,CP (obeying Subjacency), but the pied-piping is not visible because no phonological features are moved. ${ }^{31}$ The Multiple Spell-out analysis unlike the analysis presented in this paper, relies on two crucial parametric differences in UG:

a. Languages randomly have strong or weak Q-features. Languages with strong features force spell-out at the head of the chain, while languages with weak features have spell-out at the tail (due to economy of movement). To account for the Malay data, one would therefore need to

${ }^{31}$ As used in Groat \& O'Neil, pied-piping involves the percolation of the $w h$-feature to SPEC,CP, followed by the movement of the $w h$-feature to scopal position. The CP to which the $w h$-feature percolates does not undergo movement as a result of the "pied-piping." We call this type of pied-piping "covert," since it has no effect on overt word order. 
assume that in a language like Malay there are optionally strong features (i.e., both strong and weak features are possible).

b. To explain the lack of Subjacency effects in some in-situ languages (like Malay and Chinese) these languages would have to allow massive clausal pied-piping. Since in-situ languages (by assumption) must have a weak Q feature, pied-piping is covert. Languages may also exhibit overt pied-piping if the language has a strong $\mathrm{Q}$ feature causing spell-out at the head of the chain.

The main empirical problem with the Multiple Spell-out account is that this analysis has to rely on pied-piping to explain the lack of Subjacency effects when the tail of a chain is spelled out. This analysis is therefore open to the same criticism as Nishigauchi's original pied-piping approach (Nishigauchi 1990). The following arguments can be made against clausal pied-piping of $w h$-features:

1. It is unclear what determines whether a language allows "invisible" pied-piping. Since there is as yet no theory of what allows pied-piping in general, it is difficult to apply pied-piping to derive the properties of $w h$-insitu languages. However, a theory of what allows overt clausal pied-piping in languages like Quechua and Basque should also be able to predict what allows this type of covert pied-piping. Crucially, overt and covert pied-piping should obey identical restrictions. ${ }^{32}$

2. Setting aside the issue of what allows pied-piping in a particular language, the theory that combines multiple chain spell-out with pied-piping predicts that, all other things being equal, if a language allows both overt $w h$ movement and wh-in-situ (like Malay) pied-piping should be available both for overt movement (spell-out of the head) and for in-situ (spell-out of the tail). This is true in languages like Ancash Quechua, in which both overt and covert pied-piping must be assumed to exist in the Multiple Spell-out account, since both types of pied-piping have the effect of allowing a whquestion inside an island. Overt pied-piping is indicated by attaching the Qmorpheme -taq to the pied-piped constituent in (55). Crucially, in examples that would be analyzed as covert pied-piping in the Multiple Spell-out account, covert pied-piping has no morphological effect, and -taq cannot be added to the whole Relative Clause (RC), as seen in (56):

\section{Wh-In-Situ Inside an Island in Ancash Quechua (due to overt pied-}

ima-ta suwaq nuna-ta-taq (qam) kuya-nki ?
what-acc steal man-acc-Q (you) love-2pl
'You love the man who stole what?'

piping)

32 Overt pied-piping in Quechua is described in Cole (1982) and Hermon (1985), and has also been reported for Basque in Ortiz De Urbina (1986). It involves percolation from the wh-word (moved overtly to Spec, CP of its own clause) to the whole CP and has the effect of inducing overt pied-piping of the $\mathrm{CP}$, which is overtly marked as $+w h$, due to feature percolation. 
(56) Wh-In-Situ Inside an Island in Ancash Quechua (no overt pied-piping) (qam) kuya-nki ima-ta suwaq nuna-ta $-(*$ taq) ?

(you) love-2pl what-acc steal man-acc- $(* \mathrm{Q})$

'You love the man who stole what?'

However in Malay, overt clausal pied-piping is impossible. In the example below, the -kah question marker on the RC is supposed to indicate that piedpiping of the RC has taken place (-kah in Malay is equivalent to Quechua -taq), and apa 'what' is in the Spec of its own CP:

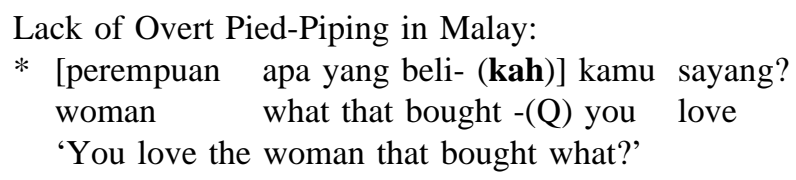

Given Minimalist assumptions, when a language has overt movement (i.e., spell-out of the head of the chain) and also allows $w h$-in-situ (spell-out of the tail), if pied-piping occurs at all, it cannot be restricted to occur only covertly (at the tail of the chain). Ancash Quechua is well behaved in this respect, but Malay is not, since in the Multiple Spell-out account for Malay pied-piping will have to occur only at the tail of the chain (covertly). Thus the combined Multiple Spell-out/pied-piping account does not appear to be an appropriate analysis for Malay.

3. Another problem faced by the pied-piping account is the facts related to $w h$ adverbial questions. In Malay, these adverbials cannot be left in-situ. In Chinese, adverbs show up in-situ but cause island violations (an argument for LF movement in these languages, see 6.1 below). As proposed in Nishigauchi (1990), pied-piping is due to feature percolation from a $w h$-word to a larger domain (usually the complex DP or CP containing the $w h$-word). It is not clear at all what would prevent feature percolation from an adverb to the island containing the adverb in this system. Nishigauchi (1990: section 3.2) argues that there may be a feature matching requirement for percolation that limits the occurrence of percolation inside RCs (which are presumably DPs and hence $+\mathrm{N}$ ) to a $+\mathrm{N} w h$-phrase only, thus ruling out feature percolation from an adverb. Following this reasoning, adverbs, that are $-\mathrm{N}$, should be able to launch feature percolation from inside adverbial adjunct islands (which are $\mathrm{CP}$ projections and hence neutral with respect to X' features, per Nishigauchi 1990:90). This is actually the situation in Turkish, as described in Özsoy (1990). In Turkish, both nominal and adverbial $w h$-words can occur inside adverbial adjuncts, and as noted by Özsoy, this directly supports a Nishigauchi type feature percolation analysis based on feature matching for Turkish. But as discussed below, adverbs cannot appear inside adverbial islands in either Malay or Chinese. ${ }^{33}$ Hence,

\footnotetext{
${ }^{33}$ Adverbial clauses are clearly not DPs in Malay and Chinese. In Korean (and perhaps also in Japanese) adverbial clauses may indeed be complements of $\mathrm{P}$ and hence could be specified as $+\mathrm{N}$ (see Kim 1996). In these languages, the feature-matching account correctly predicts that adverb wh-questions should not occur inside islands.
} 
feature percolation and clausal pied-piping fail to account for the distribution of adverbs in Malay and Chinese, suggesting that feature percolation (and hence pied-piping) is not an appropriate analysis for these languages.

We therefore reject the combined Multiple Spell-out/pied-piping analysis for Malay (and Chinese). If one adopts instead the idea that $w h$-in-situ is due to unselective binding of a $+\mathrm{N}$ variable (thus excluding adverbs), and that unselective binding is possible only if the language allows a pure variable to occur in-situ, the cross linguistic variation is explained. This is explored further for partial movement in the next section.

\subsection{Partial movement, islands and lack of meng-deletion}

\subsubsection{The asymmetry between wh-in situ and partially moved wh with respect to islandhood}

It was shown in section 4 that $w h$-in-situ and partially moved $w h$ differ in an important way: while wh-in-situ manifests no island effects, in the case of partially moved wh, island effects occur not only with regard to the path between the base position of the $w h$-word and its surface position, but also with regard to the path between the surface position of $w h$ and its understood scopal position. This was illustrated in (34)-(35) above. These facts are similar to those discussed in Saddy (1991) for Indonesian, and show that partially moved $w h$ cannot be analyzed as an instance of partial overt movement to an intermediate Spec, $\mathrm{CP}$ followed by coindexation of the partially moved wh with an operator in scopal Spec CP (as in (58)):

$$
\left[\mathrm{CP} \mathrm{OP}_{\mathrm{i}}\left[\ldots\left[\mathrm{CP} w h_{\mathrm{i}} \ldots \mathrm{t}_{\mathrm{i}} \ldots\right]\right]\right]
$$

Wh has moved from $\mathrm{t}_{\mathrm{i}}$ to intermediate Spec,CP and OP is base-generated in scopal position and binds $w h$.

The analysis in (58) is ruled out because coindexation (unselective binding for us) does not involve movement, and therefore is not sensitive to islands. Hence (58) would fail to predict that islands cannot occur between the partially moved $w h$ and the scopal Spec,CP.

Thus, we contend, the partially moved $w h$ consists of an OP+VAR that moves to non-scopal Spec,CP prior to spell-out. Subsequent to spell-out, the partially moved wh undergoes further LF movement to scopal position (as shown in option PM4, highlighted below).

Table (59) summarizes the options for partial movement (PM) in Malay. In (59) we compare two types of analyses for partially moved wh in Malay. As is well known, in many languages (e.g., German, Romani, and Hungarian) the PM construction requires the presence of a $w h$ scope marker in scopal Spec,CP (see McDaniel 1989 and Horvath 1997). On the assumption that such scope markers are wh-expletives (as proposed in Horvath 1997), we consider the possibility that Malay employs a phonologically null counterpart to the wh-expletives found in other languages: 
(59) Options for Partial Movement in Malay

\begin{tabular}{|c|c|c|c|c|}
\hline $\begin{array}{l}\text { Deri- } \\
\text { vation }\end{array}$ & $\begin{array}{l}\text { Matrix Q } \\
\text { Features }\end{array}$ & $\begin{array}{l}\text { Intermediate } \\
\text { Spec CP }\end{array}$ & $\begin{array}{l}\text { Original } \\
w h \text { site }\end{array}$ & Consequences \\
\hline PM1 & $\begin{array}{l}\text { STRONG Q } \\
\text { no null wh- } \\
\text { expletive } \\
\text { inserted }\end{array}$ & {$[\mathrm{OP}+\mathrm{VAR}\}$} & $\mathrm{T}$ & $\begin{array}{l}\text { syntactic OP movement; } \\
\text { all islands; } \\
\text { meng- deletion } \\
\text { above PM site }\end{array}$ \\
\hline PM2 & $\begin{array}{l}\text { STRONG Q } \\
\text { no null wh- } \\
\text { expletive } \\
\text { inserted }\end{array}$ & {$[\mathrm{OP} \ldots \mathrm{VAR}]$} & $\mathrm{T}$ & $\begin{array}{l}\text { syntactic OP movement; } \\
\text { all islands; } \\
\text { meng- deletion } \\
\text { above PM site }\end{array}$ \\
\hline PM3 & $\begin{array}{l}\text { STRONG Q } \\
\text { null } w h- \\
\text { expletive } \\
\text { inserted }\end{array}$ & {$[\mathrm{OP} \ldots \mathrm{VAR}]$} & $\mathrm{T}$ & $\begin{array}{l}\text { LF OP movement } \\
\text { (expletive replacement); } \\
\text { all islands; no meng- } \\
\text { deletion above PM site }\end{array}$ \\
\hline PM4 & $\begin{array}{l}\text { STRONG Q } \\
\text { null } w h \text { - } \\
\text { expletive } \\
\text { inserted }\end{array}$ & {$[\mathrm{OP}+\mathrm{VAR}]$} & $\mathbf{T}$ & $\begin{array}{l}\text { LF OP movement } \\
\text { (expletive replacement); } \\
\text { all islands; no meng- } \\
\text { deletion above PM site }\end{array}$ \\
\hline
\end{tabular}

On the assumption that scopal Q is invariably STRONG, an immediate question arises: How is the STRONG feature of scopal Q checked off when $\mathrm{PM}$, by definition, involves movement of $w h$ to a non-scopal Spec,CP prior to spell-out? Bearing this question in mind, we consider two types of derivations, those in which a null $w h$-expletive is hypothesized (comparable to the overt wh-expletive was in German) as in PM3 and PM4, and those in which no such expletive is proposed, as in PM1 and PM2. ${ }^{34}$ Turning to the derivations in (59), PM1 is ruled out either because no $w h$-word (neither the $w h$-OP nor a $w h$-expletive) occurs in the scopal Spec,CP to check off the STRONG feature (if further movement, prior to spell-out, of OP to Spec,CP is not assumed), or because OP would have to be separated from VAR to check the STRONG feature in scopal Spec,CP. However, we have assumed throughout that once OP and VAR are combined in the lexicon, they cannot separate prior to spell-out, so PM1 has an unchecked STRONG Q feature.

\footnotetext{
${ }^{34}$ We assume that the $w h$-expletive satisfies the feature checking requirements of the scopal Q, but because the expletive has no semantic content, and therefore is not an operator, it does not satisfy the Variable Binding Condition.
} 
In PM2 OP moves to scopal Spec,CP and thereby checks off the STRONG feature of Q, but PM2 is ruled out because in PM2 the variable and the operator are not combined. Thus, the variable (the question word) would not be pied-piped into the intermediate Spec,CP when the operator passes through that position. As a result, while in PM2 the STRONG feature is checked off, the derivation is not possible since only when OP and VAR are combined can PM occur at all.

PM3 is ill formed for the same reason as PM2. While the STRONG feature of Scopal Q is checked off by the wh-expletive, as in PM2, PM (and overt wh-movement in general) is not possible unless an OP+VAR configuration obtains.

Finally, PM4 is well-formed because the null wh-expletive satisfies the STRONG feature of Q. Overt movement of $w h$ to the intermediate Spec,CP is possible because OP and VAR are combined lexically to form a single unit. Subsequent to spell-out, OP moves to scopal Spec,CP to satisfy the requirement that $w h$-questions manifest an operator-variable structure (the Variable Binding Condition). ${ }^{35}$ According to PM4, the original site of $w h$ and the scopal Spec of CP are related by movement. So it is correctly predicted that islands will be respected along the entire path, and not just along the overt portion. Since overt movement takes place prior to spell-out, it is also predicted correctly that meng-will be omitted between the underlying site of wh and its position at spell-out. However, since post-spell-out movement cannot, by definition, be reflected in pronunciation, it is also expected that meng-will not be omitted between the surface position of $w h$ and the scopal Q.

We have argued that the relationship between the partially moved $w h$ and the scopal Spec,CP must be LF movement. There is, in fact, strong empirical support for that claim. Let us consider as a straw man the possibility that the relationship between the surface and scopal positions is syntactic operator movement. As illustrated in section 3.2, examples (29)-(30), operator movement in the syntax, just like overt $w h$-movement, results in the obligatory omission of meng-. Thus meng- is deleted in both Relative Clauses and Focus constructions, presumably due to OP movement. Hence, if the covert movement associated with partial wh-movement were syntactic operator movement, it would be expected that meng-would be omitted between the surface position of $w h$ and its scopal position. But this is not the case, since, as shown in example (41), meng-is not deleted above the PM site. As a result, syntactic operator movement (i.e., movement before spell-out) is not only an impossible analysis on the basis of Minimalist assumptions, but is to be rejected on empirical grounds as well.

In contrast to syntactic operator movement, LF movement takes place subsequent to spell-out, predicting correctly the possibility of meng-between the PM site and the scopal position of the wh-OP. PM4, then, correctly

\footnotetext{
${ }^{35}$ Or, alternately, OP moves to scopal Spec,CP to satisfy the requirement that expletives must be replaced prior to LF.
} 
predicts all the seemingly peculiar properties of the PM construction in Malay.

The lack of meng- deletion above the PM site and the existence of island effects above this site also make it difficult to analyze PM as Multiple Spellout. (See section 5.4 for why this type of analysis was rejected for $w h$-in-situ.) At first glance, PM seems like the prime example for the Multiple Spell-out account. If it were to be assumed that in this instance there is a weak Q feature and, hence, (following Groat \& O'Neil 1996) only wh-features are moved to scopal Spec,CP to check the Q feature, it would be predicted that spell-out would not occur at the head of the chain. However, note that this merely allows for the option of spelling out the $w h$-word in-situ, and does not provide an explanation for why the $w h$-word appears overtly in an intermediate Spec,CP.

In addition, Multiple Spell-out cannot account for the islandhood and mengdeletion facts in the PM construction. Unlike $w h$-in-situ, partially moved $w h$ obeys island conditions. In the spell-out account this means that pied-piping of the category (the $w h$-word) must somehow be blocked once the $w h$ has moved out of its original base generated position. It is entirely unclear what would prevent $w h$-feature percolation and pied-piping in this case. In addition, if PM involved a chain created by feature movement from the partially moved $w h$ to scopal Spec,CP, it is unclear why meng- deletion should not take place. ${ }^{36} \mathrm{We}$ therefore do not see what advantages the Multiple Spell-out analysis offers over the expletive replacement account adopted here.

To summarize, the architecture of the system we are employing predicts the existence of the seemingly idiosyncratic facts found in Malay. In the section that follows we turn from a Malay specific perspective on $w h$ questions to a cross linguistic perspective, and examine the extent to which the degree of variation predicted by the system we employ corresponds to the variation actually found across natural languages.

\section{The Typology of Wh-Movement}

In this section we examine the extent to which our analysis for Malay makes correct predictions about the properties of $w h$-questions in other languages. We show that the facts of Chinese and English are predicted by the analysis.

\subsection{Chinese and similar languages ${ }^{37}$}

Chinese differs from Malay in two ways. First, argument $w$ h-question words do not display the full range of options possible in Malay. Rather, they are

\footnotetext{
${ }^{36}$ To account for the lack of meng- deletion, the Multiple Spell-out account would have to assume that feature-movement (as opposed to abstract OP movement in focus and RC constructions) does not affect morphology.

${ }^{37}$ Japanese, like Chinese, exhibits $w h$-in-situ and has been described as a language in which $w h$-words are pure variables and can be bound by non Q operators. We would thus predict that
} 
always in-situ and show no sensitivity to islands. Secondly, unlike Malay, adverbial $w h$-words also appear in-situ. In the case of adverbials, however, there is evidence of covert movement since adverbial wh-words cannot occur in islands (see Huang 1982, Tsai 1994 inter alia). The problem for our analysis is how the differences between Chinese and Malay might be predicted. Of particular interest is whether our analysis predicts correctly that Chinese wh-adverbs will remain in-situ but will nonetheless be sensitive to islands.

We shall make the following assumption about the lexicon of Chinese: Unlike Malay, wh-words are invariably OP...VAR rather than OP+VAR. On the basis of this lexical property and Minimalist principles, the differences between Malay and Chinese will fall out without further stipulation.

Consider the possible derivations for Chinese, as summarized in the following table:

(60) Options for Wh-Questions in Chinese

\begin{tabular}{|c|c|c|c|}
\hline & Matrix C & $w h$-in-situ & Consequences \\
\hline NP1 & $\begin{array}{c}\text { STRONG Q } \\
\text { OP ... }\end{array}$ & VAR & $\begin{array}{l}\text { in-situ; } \\
\text { unselective binding; } \\
\text { no island effects }\end{array}$ \\
\hline NP2 & STRONG Q & [OP...VAR] & $\begin{array}{l}\text { OP movement; } \\
\text { all islands obeyed }\end{array}$ \\
\hline ADV1 & STRONG Q & OP ...VAR & $\begin{array}{l}\text { Unselective binding } \\
\text { impossible }\end{array}$ \\
\hline ADV2 & STRONG Q & [OP...VAR] & $\begin{array}{l}\text { OP movement; } \\
\text { all islands obeyed }\end{array}$ \\
\hline
\end{tabular}

We shall first examine $w h$-NP. NP1 and NP2 are based on the same numeration, and both derivations converge, so they are in competition. NP1 involves the merger of OP to the scopal $\mathrm{C}$ (unselective binding of the $w h$ word), while NP2 involves movement of OP to scopal Spec,CP. Since merger is more economical than movement, NP1 is preferred, and NP2 is blocked.

\footnotetext{
$+\mathrm{N} w h$-in-situ should be exempt from all island constraints, while adverbial $w h$ would be forced to launch abstract OP movement (or move at LF). The latter is certainly not disputed: all descriptions of Japanese seem to agree that adverbs like naze 'why' are not allowed inside islands and similar facts are reported for Korean way 'why' (see Kim 1996).

There is some disagreement about whether other (argument) wh-in-situ can appear inside all islands. Some researchers (Takahashi 1993) describe the facts as similar to the ones in Chinese. Others (most notably, Nishigauchi 1990 and Watanabe 1993) have claimed that $w h$-in-situ is not possible inside a $w h$-island. We will assume that the facts in Japanese are identical to the facts in Chinese, the only major difference being that in Japanese (and Korean) the equivalent of 'how' (doo in Japanese and ettekhey in Korean) has the same distribution as wh-NPs and is not subject to island constraints. Further research in Japanese and Korean will have to determine whether the facts are indeed identical to the Chinese facts.
} 
Turning to wh-adverbials, ADV1 is not a possible derivation because unselective binding is impossible for $w h$-adverbials. Thus, the only possible derivation is ADV2: In ADV2 the STRONG feature of the matrix $\mathrm{C}$ is checked off by movement of OP to matrix Spec CP prior to spell-out. Thus, given that in Chinese question words are always VAR rather than OP+VAR, both the properties of questions in Chinese and the differences between Chinese and Malay fall out automatically.

It should be noted, however, that it was argued by Tsai (1994) that whadverbials in Chinese are invariably OP+VAR. The basis for this claim is the fact that the distribution of $w h$-adverbials in Chinese is different from that of $w h$-NPs. For instance, while shenme 'what' can be bound by an existential quantifier and mean 'something', weishenme 'why' cannot be bound in the same way and mean 'for some reason':

(61) a. Ruguo Akiu mai-le shenme, ta yiding hui lai gaosu wo.

if Akiu buy-prf what he surely will come tell me

'If Akiu bought something, he surely would come tell me.'

b. *Ruguo Akiu weishenme buneng jiao zuoye, ta yiding hui lai gaosu

WO.

if Akiu why cannot hand-in homework he definitely will come tell

me

'If Akiu for any reason could not hand in his homework, he would definitely tell me.'

Examples like (61b) (and similar sentences involving dou 'all' quantification) are taken by Tsai to constitute evidence that wh-adverbials like weishenme cannot be instances of VAR, and are rather "intrinsic operators," i.e., $\mathrm{OP}+\mathrm{VAR}$.

While examples like (61b) appear initially persuasive, Tsai provides examples that show that weishenme can in fact be bound by a noninterrogative operator:

(62) Akiu weishenme gaoxing, wo jiu weishenme shang-xin.

Akiu why happy I then why hurt-feeling

'I am hurt for whatever reasons Akiu is pleased.'

Sentence (62) appears to have a logical structure in which weishenme is a variable ranging over reasons for being happy. This variable is bound by the universal quantifier. ${ }^{38}$ Thus, (62) shows that weishenme can be bound by a non-interrogative operator, and, at least in (62), must be VAR rather than $\mathrm{OP}+\mathrm{VAR}$.

If weishenme is a variable rather than OP+VAR, what accounts for the ungrammaticality of the binding of weishenme by an existential quantifier in

38 See Cheng \& Huang (1996). It should be noted that an alternative account in which weishenme gaoxing and weishenme shangxin are headless relative clauses can be ruled out since question words are not used in headless relative clauses in Chinese. 
(61b)? Tsai is correct in noting that the existence of examples like (62) does not undercut the existence of a noun-adverb asymmetry since adverbs like weishenme are bound in different environments from those in which nouns like shenme 'what' are bound. A plausible explanation for the asymmetry is that nouns like shenme and shei 'who' are restricted to individual entities (non-human and human respectively). In contrast, weishenme ranges over propositions rather than individuals. This suggests that the difference between $w h$-nouns and wh-adverbs is semantic. While both are variables, each is restricted to being bound by a different type of operator: the quantifier in (61) binds individual entities, so it can bind shenme but not weishenme. In contrast, the quantifier in (62) binds propositions. Thus it can bind propositional variables such as weishenme but not individuals entities.

Therefore, we take the existence of sentences like (62) in Chinese as empirical confirmation that all $w h$-forms in Chinese, regardless of grammatical category, are instances of VAR rather than OP+VAR. In contrast, in Malay, we have not been able to find any environment in which kenapa 'why' or bagaimana 'how' can be interpreted as a variable bound by a noninterrogative operator. Note that sentences similar to (62) are ill-formed in Malay:
*Ali kecewa kenapa-pun saya gembira.
Ali disappointed why-also I happy
'Ali is disappointed for whatever reasons I am happy.'

We thus conclude that in Malay kenapa and bagaimana are invariably OP+VAR. ${ }^{39}$

\subsection{English and similar languages}

English and most European languages differ from Malay and Chinese in that OP and $w h$ are always joined to constitute a single word. Presumably, UG permits the generation of OP in scopal position to check the STRONG Q feature, but the nonexistence of OP separate from the wh-variable in the lexicon of English rules out unselective binding as an option. The fact that

39 We have argued that sentences like (63) are ungrammatical because Malay $w h$-adverbials appear in the lexicon as OP+VAR. This would predict that while kenapa and bagaimana are lexicalized as OP+VAR, other $w h$-adverbs might be lexicalized differently. There is in fact at least suggestive evidence that this is the case. While formal Malay bagaimana 'how' was seen to be ungrammatical in (54), colloquial Malay macam mana 'how' is well formed:

(i) Saya tak boleh belajar macam mana-pun.

I not can study how-also

'I cannot study for any reason.'

This suggests that macam mana differs from bagaimana in permitting both OP+VAR and VAR alone.

There is, however, another analysis possible for macam mana. It is possible that macam mana is analyzed by speakers as macam 'like' + mana 'which', analogous to buku mana 'which book'. If this analysis is correct, macam mana is an instance of a $w h$-NP meaning 'in which way', and not a $w h$-adverbial like bagaimana. 
$\mathrm{OP}$ and VAR are invariably combined in a single word eliminates the possibility of OP being inserted as the specifier of CP while the $w h$-VAR stays in-situ. The lexical merger of OP and $w h$ also eliminates the option of covert OP movement in the syntax since OP and wh would be separate in this case as well. LF wh-movement is also blocked because the STRONG feature on $\mathrm{Q}$ must be checked before spell-out.

As predicted, in English wh-words cannot be bound by other operators. PM is not an option, since the STRONG Q feature must be checked prior to spell-out, and (as discussed below) English does not have an alternative device (such as a wh-expletive that moves to the Spec,CP) that could check this feature. The only possible derivation for English is as follows:

(64) Options for Wh-Questions in English

\begin{tabular}{lll}
\hline Matrix C & wh-in-situ & Consequences \\
\hline STRONG Q & {$[$ OP+VAR] } & Overt movement; all islands obeyed \\
\hline
\end{tabular}

Of course, once a STRONG feature is checked by the [OP+VAR] moving into Spec,CP, additional $w h$-words can stay in-situ and can be bound by the OP in the scopal position via unselective binding (as was argued by Reinhart 1993). This explains why the wh-in-situ then does not obey any islands constraints in the multiple wh-construction.

\section{Conclusions}

In this paper we have examined the extent to which the facts of $w h$-movement can be captured in a deterministic theory of syntax based on Minimalist principles. The various options for $w h$-question formation in Malay present a particular problem for such a theory because $w h$-questions in Malay include a considerable variety of options, among them $w h$ that is moved to scopal Spec,CP, wh-in-situ, and partial $w h$-movement. Furthermore, the language appears to manifest a number of language specific constraints on wh-questions such as the requirement that certain question words undergo obligatory, overt movement and that some verbal prefixes must be omitted when certain types of $w h$-questions are formed. The challenge for a deterministic theory of wh-questions is to predict just which options will occur under which circumstances, and what the properties of each option will be. In addition, the same principles employed for Malay must predict how Malay will differ from previously studied languages like Chinese, Japanese, and English.

Our analysis has been based on a few central principles of the Minimalist Program like Full Interpretation, movement motivated by the need to discharge features and a single economy principle, which specifies that Merge is more economical than Move. While no parametric variation in grammatical principles is permitted, certain lexical variation is posited. Specifically, following Watanabe (1993), Tsai (1994), Aoun \& Li (1993), and 
others, we propose that languages differ with regard to whether wh-words consist of an interrogative operator, or of a $w h$-variable bound by a null interrogative operator. This single lexical difference explains most of the variation found, both within Malay and between Malay and other languages and it obviates the need for parametric variation with respect to feature strength for the Q-feature in the $\mathrm{C}$ head. We can thus maintain (following Chomsky 1995) that Q-features are universally STRONG, even in languages like Malay and Chinese, which exhibit wh-in-situ. We believe that the success of Minimalist principles in predicting the great surface diversity seen in the languages considered constitutes strong evidence for the fruitfulness of this approach.

\section{References}

AISSEN, J. 1996. Pied-piping, abstract agreement, and functional projections in Tzotzil. Natural Language and Linguistic Theory 14:447-491.

ALSAGOFF, L. S. 1992. Topic in Malay: The other subject. Ph.D. dissertation, Stanford University, Palo Alto, California.

AOUN, J. \& A. LI. 1993. Wh-elements in-situ: Syntax or LF? Linguistic Inquiry 24:199-238.

CHENG, L. 1991. On the typology of wh-questions. Ph.D. dissertation, MIT, Cambridge, Mass.

CHENG, L. \& C. T. J. HUANG. 1996. Two types of donkey sentences. Natural Language Semantics 4:121-163.

CHOMSKY, N. 1993. A minimalist program for linguistic theory. In The view from building 20, ed. K. Hale \& S. J. Keyser, 1-52. Cambridge, Mass.: MIT Press.

CHOMSKY, N. 1995. The minimalist program. Cambridge, Mass.: MIT Press.

CHUNG, S. 1994. Wh-agreement and "referentiality" in Chamorro. Linguistic Inquiry 25:1-44.

CINQUE, G. 1990. Types of A-dependencies. Cambridge, Mass.: MIT Press.

COLE, P. 1982. Imbabura quechua. Lingua descriptive series. The Hague: North Holland.

COLE, P. \& G. HERMON. 1995. Is wh-in-situ really in-situ: Evidence from Malay and Chinese. In Proceedings of the thirteenth West Coast conference on formal linguistics, ed. R. Aranovich et al, 189-204. Center for the Study of Language and Information, Stanford University, Palo Alto, California.

COLE, P. \& G. HERMON. 1997. Apa yang "apa yang"? Paper presented at the Symposium on Malay and Indonesian Linguistics, Universiti Sains Malaysia, Penang, Malaysia, January 14-15.

COMOROVSKI, I. 1986. Multiple wh-movement in Romanian. Linguistic Inquiry 17:171-177.

GEORGOPOULOS, C. 1985. Variables in Palauan syntax. Natural Language and Linguistic Theory 3:59-94.

GUILFOYLE, E., H. HUNG \& L. TRAVIS. 1992. Spec of IP and spec of VP: Two subjects in Austronesian languages. Natural Language and Linguistic Theory 10:375-414.

GROAT, E. \& J. O'NEIL. 1996. Spell-out at the LF interface. In Minimal ideas: syntactic studies in a minimalist framework, ed. W. Abraham, S. D. Epstein, H. Thrainsson \& C. J.-W. Zwart, 113-141. Amsterdam: John Benjamins.

HEIM, I. 1982. The semantics of definite and indefinite noun phrases. Ph.D. dissertation, University of Massachusetts, Amherst. 
HERMON, G. 1985. Syntactic modularity. Dordrecht: Foris.

HERMON, G. \& P. COLE. In preparation. The typology of partial movement: Evidence from Malay. Ms., University of Delaware, Newark.

HORVATH, J. 1997. The status of "wh-expletives" and the partial wh-movement construction of Hungarian. To appear in Natural Language and Linguistic Theory.

HUANG, C. T. J. 1982. Logical relations in Chinese and the theory of grammar. Ph.D. dissertation, MIT, Cambridge, Mass.

KAYNE, R. 1994. The antisymmetry of syntax. Cambridge, Mass.: MIT Press.

KADER, M. 1976. The syntax of Malay interrogatives. Ph.D. dissertation, Simon Fraser University, Canada.

KIM, S. 1996. The Q-operator strategy for the $w h$-in situ phrases in Chinese, Korean, and Japanese. Ms., University of Delaware, Newark.

KOOPMAN, H. \& D. SPORTICHE. 1982. Variables and bijection principle. In Projet sur les langues kru: Premier Rapport, ed. J. Kaye, H. Koopman \& D. Sportiche. Montreal: Dept. de la Ling., Univ. du Quebec, Montreal.

MANZINI, M. R. 1996. Minimalism and the theory of locality. Ms., Universitá di Firenze. (To be published in the Proceedings of the specifier conference, University of York, Oxford University Press.)

MARTOHARDJONO, G. 1993. Wh-movement in the acquisition of a second language: A cross-linguistics study of three languages with and without overt movement. Ph.D. dissertation, Cornell University, Ithaca, NY.

McDANIEL, D. 1989. Partial and multiple wh-movement. Natural Language and Linguistic Theory 7:565-604.

NISHIGAUCHI, T. 1990. Quantification in the theory of grammar. Dordrecht: Kluwer.

ORTIZ DE URBINA, J. 1986. Some parameters of the grammar of Basque. Ph.D. dissertation, University of Illinois at Urbana-Champaign.

OUHALLA, J. 1996. Remarks on binding properties of wh-pronouns. Linguistic Inquiry 27:676-708.

ÖZSOY, A. S. 1990. A'-dependencies in Turkish. In Current issues in Turkish linguistics 1, ed. B. Rona, 139-158. Ankara, Turkey: Hitit Yayinevi Publishers.

REINHART, T. 1993. Wh-in-situ in the framework of the minimalist program. In OTS working papers, Research Institute for Language and Speech, Utrecht University, Utrecht, The Netherlands.

REINHART, T. 1995. Interface strategies. In OTS working papers, Research Institute for Language and Speech, Utrecht University, Utrecht, The Netherlands.

RIZZI, L. 1991. Residual verb second and the wh-criterion. Ms., University of Geneva, Geneva.

RIZZI, L. 1992. Argument/Adjunct (A)symmetries. In Proceedings of NELS 22, 365381. GSLA, Department of Linguistics, University of Massachusetts, Amherst.

ROGAYAH, A. R. 1995. The syntax and semantics of quantification in Malay: A government and binding approach. Ph.D. dissertation, Universiti Sains Malaysia, Penang, Malaysia.

RUDIN, C. 1988. On multiple questions and multiple wh-fronting. Natural Language and Linguistic Theory 6:445-501.

SADDY, D. 1991. Wh-scope mechanisms in Bahasa Indonesia. In More papers on whmovement, MIT Working papers in linguistics 15, ed. L. Cheng \& H. Demirdash, 183-218. Department of Linguistics and Philosophy, MIT, Cambridge, Mass.

SADDY, D. 1992. A versus A-bar movement and wh-fronting in Bahasa Indonesia. Ms., University of Queensland, Australia.

SELLS, P. 1984. Syntax and semantics of resumptive pronouns. Ph.D. dissertation, University of Massachusetts, Amherst.

TAKAHASHI, D. 1993. Movement of $w h$-phrase in Japanese. Natural Language and 
Linguistic Theory 11:655-678.

TURANO, G. 1995. On indefinite elements in Albanian. Ms., Universitá di Firenze, Firenze, Italy.

TSAI, D. 1994. On economizing the theory of A'-dependencies. Ph.D. dissertation, MIT. Distributed by the MIT working papers in linguistics, Cambridge, Mass.

WATANABE, A. 1993. Subjacency and s-structure movement of wh-in-situ. Journal of East Asian Linguistics 1:255-291.

Peter Cole

University of Delaware Department of Linguistics 46 East Delaware Avenue

Newark, DE 19716 pcole@UDel.edu

Gabriella Hermon University of Delaware Department of Linguistics 46 East Delaware Avenue Newark, DE 19716 gaby@UDel.edu 